University of Louisville

ThinkIR: The University of Louisville's Institutional Repository

Electronic Theses and Dissertations

1942

\title{
A survey of the audio-visual aids being used by the Louisville white fourth, fifth, and sixth grade teachers.
}

Olga Schmutz

University of Louisville

Follow this and additional works at: https://ir.library.louisville.edu/etd

Part of the Educational Methods Commons

\section{Recommended Citation}

Schmutz, Olga, "A survey of the audio-visual aids being used by the Louisville white fourth, fifth, and sixth grade teachers." (1942). Electronic Theses and Dissertations. Paper 1900.

https://doi.org/10.18297/etd/1900

This Master's Thesis is brought to you for free and open access by ThinkIR: The University of Louisville's Institutional Repository. It has been accepted for inclusion in Electronic Theses and Dissertations by an authorized administrator of ThinkIR: The University of Louisville's Institutional Repository. This title appears here courtesy of the author, who has retained all other copyrights. For more information, please contact thinkir@louisville.edu. 


\title{
UNIVERSITY OF LOUISVILLE
}

\author{
A SURVEY OF THE AUDIO-VISUAL AIDS BEING \\ USED BY THE LOUISVILLE WHIIE FOURTH, \\ FIFTH, AND SIXTH GRADE TEACHERS
}

\author{
A Dissertation \\ Submitted to the Faculty \\ Of the Graduate School of the University of Louisville \\ In Partial Fulfiliment of the \\ Requirements for the Degre日 \\ Of Master of Arts
}

Department of Education

By

OLGA SCHMUTZ

Year

1942 
NAME OF STUDENT: OLGA SCHMUTZ

TITLE OF THESIS: A SURVEY OF THE AUDIO-VISUAL AIDS

BEING USED BY THE LOUISVILLE WHITE

FOURTH, FIFTH, AND SIXTH GRADE TEACHERS

APPROVED BY READING COMMTTTEE COMPOSED OF THE FOLLOWING MEMBERS:

NAME OF DIRECTOR:

DATE: JuIJ 23; 1942. 
A SURVEY OF THE AUDIO-VISUAL AIDS BEING USED BY THE LOUISVILLE WHTTE FOURTH, FIFTH, AND SIXTH GRADE TEACHERS 
TABLE OF CONTENTS

CHAFIER

PAGE

I. Statement of the Problem -mmanmmannm

II. H1story of Audio-Visual Ald Movement -n

III. Types of Audio-Visual Alds Framined in the Survey - Theix Advantages and Iimi-

tations in Instruction

School Journey

Objects, Specimens, and Models .......Graphs, Charts, and Dlagrams .......... Maps and Globes Mounted P1ctures -......................

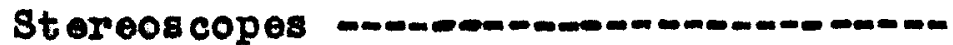

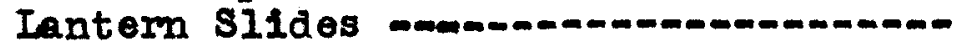
Opeque Projector Filmstrips anmonan Motion Pictures -

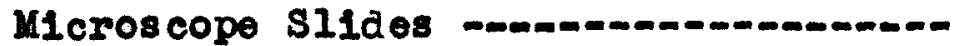

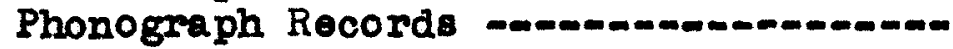

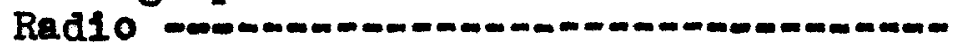

IV. Appraisal of Audio-Visual Alds Based on Some Outstanding Research

Experiments :

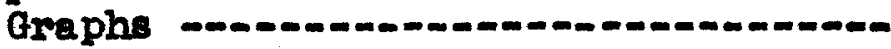

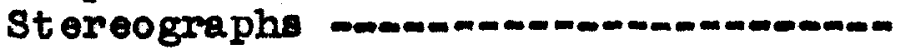

Lant erm SIIdes

F1Imstrips -mon-mon

Motion Pletures (Silent)

Motion Pletures (Sound)

Rad10

37

39

40

41

$43-51$

$51-55$

V. A Survey of the Audio-Visual Alds Being Us od by the Louisvilie White Fourth, Flfth, and S1xth Grade Teachers -........ 
Different Types of Alds Being Used -.- 59 Extent of Use of Audio-Visual Aids --. 59-70 Reasons Listed by Teachers for Not Using Audio-Visual Aids _......... 70-73 Audio-Visual Aids Unknown to Teachers- 73-74 Audio-Visual Aids About Which Teachors Desire More Information _..... 74-76 Audio-Visual Aids in Which Teachers Are Most Interested _... 76-79 Methods of Use Value of Audio-Visual Aids When Supplemented with Books in Instruction - $97-99$ Suggestions and Recommendations Made by Louls vil1e Teachers for EstabIlshing an Audio-Visual A1d Program- 99-102

VI. Conclusions and Recommendations --n-n 103

Bibllography - 109

Appendix 
LIST OF TABLES

TABLE

PAGE

I. Use of Audio-Visual Alds by Two thundred Louis ville White Fourth, Fifth, and Sixth Grade Teachers

II. Extent of Use of Audio-Visual Alds by Two Hundred Louisville White Fourth, Fifth, and Sixth Grade Teachers .........

III. Aids with Which a Number of Louisvilie White Fourth, Fifth, and Sixth Grade Teachers are Unfamiliar .......................

IV. Audio-V1sual Alds about Which Teachers Desire More Information

v. Audio-Visual Aids in Which Teachers Are Most Interested ....

VI. Ways in Which Maps and Globes Best Answered the Needs of One Fundred and NinetyTwo Louisville White Fourth, Fifth, and

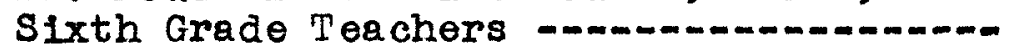

VII. Ways in Which Mounted Pictures Best Answered the Needs of One Hundred and ElghtyFour Louisville White Fourth, Fifth, and

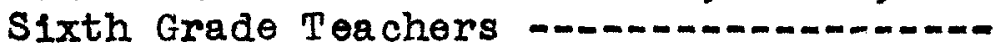

VIII. Ways in Which Charts and Diagrams Best. Answered the Needs of one Hundred and S1xty-Four Louis ville White Fourth, Fifth, and Sixth Grade Teachers ......... 
IX. Ways in Which Objects, Specimens, and Models Best Answered the Needs of One Hundred and Forty-Six Iouisville White Fourth, Fifth, and Sixth Grade Teachers-

X. Ways in Which Graphs Best Answered the Neods of One Hundred and Forty-Four Lou1s ville White Fourth, Fifth, and Sixth Grade Teachers -

XI. Ways in Which Radio Best Answered the Needs of One Hundred and Forty Louisville White Fourth, Fifth, and Sixth

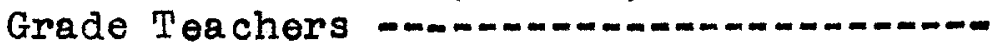

XII. Ways in Which Excursions Best Answered the Needs of One Hundred Louisville White Fourth, Fifth, and Sixth Grade Teachers - -

XII. Ways in Which Motion Pictures Best Answered the Needs of Ninety-Six Louisville White Fourth, Fifth, and Sixth Grade

Teachers -

XIV. Ways in Which Phonograph Records Best Answered the Needs of E1ghty Loulsville White Fourth, Fifth, and Sixth Grade

Teachers -....

XV. Ways in Which Lentern Slides Best Answered the Needs of Twenty-EIght Lou1sville White Fourth, Fifth, and Sixth Grade Teachers 
TABIE

XVI. Ways in Which Stereoscopes Best Answered the Needs of Twenty-Four Lou1sville White Fourth, Fifth, and Sixth Grade Teachers _...

XVII. Ways in Which Filmstrips Best Answered the Needs of Twenty-Two Louisville White Fourth, Fifth, and Sixth Grade Teachors-

XVIII. Ways in Which Microscope Slides Best Answered the Needs of Twelve Louisville White Fourth, Fifth, and Sixth Grade Teachers

XIX. Ways in Which Audio-Visual Aids Aro Valuable in Instruction Whon Supplemented with Books 


\section{IIST OF FIGURES}

FIGURE

PAGE

1. Extent of Use of Motion Pictures by Louisville White Fourth, Fifth, and

Sixth Grade Teachers

2. Extent of Use of Phonograph Records by Louisvilie White Fourth, Fifth, and

Sixth Grade Teachers

3. Extent of Use of Excursions by Iouisvilie White Fourth, Fifth, and Sixth Grade Teachers

4. Extent of Use of Iantern Slides and Stereoscopes by Loulsvilie White Fourth, Fifth, and Sixth Grade Teachers -......

5. Extent of Use of Filmstrips by Louisvilie White Fourth, Fifth, and Sixth

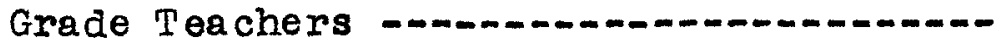


STAT EMENT OF THE PROBLEM 


\section{CHAPTER I}

\section{STATEMENT OF PROBLEM}

The investigator has been a teacher in the Louisville elementary schools for the last seventeen yoars, sixteen of which have boen at her present school, the George W. Morris. This school is composed of many chlldren whose parents have comé from forelgn lands such as Syrla, Italy, Poland, Russia, Greece and Germany. Besides the forelgn element this school also has many retarded children. Therefore, in order to solve the varied problems of these two groups of children, the invest1gator turned more and more to the use of audio-visual aids, which she found very effective in her instruction. As her needs for more audio-visual a id materials increased, the writer became concerned with the needs of other Louisvilie elementary teachers, and thus decided to make a survey of the audio-visual aid materials being used by them. This study is therefore concerned with:

A. What are the different types of audiovisual alds available to the Loulsville elementary teachors? What are the advantages and limitations of these aids in instmaction?

B. What are some of the important scientific 
experiments that have been made which evaluate the uses of audio-visual aids in the classroom?

C. What are the types, the frequencies of use, and the methods of presentation of the audio-visual a1ds being used by the Louisville white fourth, fifth, and sixth grade teachers? What are the aids in which these teachers are most interested and regarding which do they desire more information? In what ways are audio-visual alds a veluable media when supplemented with books in instruction?

D. What are the suggestions and recommendations for future use of this type of material as revealed by the questionnaire mailed to these teachers?

In order to answer " $A$ " and " $B$ " a study was made of all the important literature on this subject. In reviewing the experiments, the investigator confined herself to those she considered most outstanding. This information is given in Chapter IV.

In order to answer " $C$ " and " $D$ " a questionnaire was sent to every Louisville white fourth, fifth, and sixth grade teacher. The results of this questionnaire are found in Chapter $V$. A copy of this questionnalre is included in the appendix. 
As far as the writer has been able to determine, no survey of this type has ever been made in the Loulsville public schools. While the writer does not contend that the results of this survey are all inclusive, these findings do reveal the prevalent practices of the Louisville teachers. It is hoped that others, a Iso interested in the field of audio-visual a 1ds, will bo stimulated by this study to continue more research in the Loulsville schools along this problem.

Before discussing the different types of audiovisual aids found in the Louisville elementary schools, a brief history of this movement will be presented in the following chapter. 
HISTORY OF AUDIO-VISUAL AID MOVEMENT 


\section{HISTORY OF AUDIO-VISUAL AID MOVEMENT}

Some people have criticized visual alds as being new "frills and fads" of education which would soon disappear from our schools. However, if the history of visual alds is traced, it is easily percelved that they are far from new but very, very old. In fact, probably the first visual alds were used by prehistoric man - crude but plain drawings made on the walls of the caves either to warn his fellow-man of approaching danger or deplcting events in his 11 fe which he wanted portrayed. Many caves containing such drawings have been found in France and Spain.

Iater the Egyptians continued using "visual alds" for on the walls of the pyramids, temples, and obelisks were found pictures to depict the life of the EgJptians. The Egyptians also developed a picturelanguage which proved of great assistance in revealing the history of the Nile Valley to future historians.

The Greeks developed intellectuel instruction in which objective materials as well as the spoken and written word taught history and civic ideals. Music and the drama, painting and sculpture were not merely for artistic expression. Music was used to induce a war-like, peaceful, or 
luxurious mood; the drama was visual instmaction in moral and political attitudes; painting and sculpture, especialiy in public bulldings, commemorated historical and religlous events. 1

The ancient Greeks also were among the first to utilize the journey as an aid in instruction, for they soon realized the value of going direct to the natural situation for first-hand knowledge.

"In that age it was a common sight in Athens and its environs to seo the venerable Socrates and his disciples here and there in the practice of observation, discussion, and meditation." 2

The Romens realized the value of visual alds employing art (sculpturing and bas rellef on columns) to inform the populace of such important events as victories in war, or acts of heroism in battle. Visual aids were also used in some of the Roman schools.

Cicero approved of visual forms as devices for remembering abstractions. Seneca favored visual teaching on the ground that men believe visual above other perceptions. Quintilian, who recognized that interest helps the child to absorb knowledge, conceived of teaching the alphabet by games played with solid letters carved out of wood or I ivory blocks. 3

Coming down to the Middle Ages the Church conveyed many messages of faith and piety to their followers by means of stained glass windows, painting, and sculpturing.

1. Wendell Thomas, "The stream of Perceptual Teaching, Educational Screen, November, 1939, p. 326.

2. Charles Hoban, Charles Hoban Jr., and Samuel Z1sman, V1sualizing the Curriculum (New York: The Cordon Company, 193\%), p. 30.

3. Wendell Thomas, op. c1t., p. 326. 
During an age of falth when the paramount ideal was an exposition of Christianity, when manuscript books were few, possessed only by scholars and by the extremely wealthy, it is well to note the practical dependence upon the "visual" alone as the chief means of instmucting.

At no time did the invention of printing put an end to this stream of reliance upon the visual. It is quite apparent, however, that after the middle of the Fifteenth Century the old arts of sculpture and stained glass visibly declined. But conversely the printed book and its illustrations steadily improved.4

In 1658 Comenius published "Orbis Pictus", the first 1llustrated textbook for children, as he belleved that words alone were insufficlent for learning.

He, therefore, appealed to the eye and the mind of the pupil through the skill of the artist. Words were clarified and Impressed by pictures or by the - thing itself when possible. His World Illustrated became the most popular school book In Europe and held that place of distinction for nearly a century.$^{5}$

Pierre Nicole, a contemporary of Comenius, believed that children should be taught through their senses, and that a new subject should always be approached by means of an appeal to their sight and hoaring. 6 He believed this so thoroughly that such visual alds as maps, pictures, globes and flashcards were constantly employed in his teaching.

In 1690 the "New England Primer" was published which was used for over a hundred years. In 1710 "The

4. Manson MIIner Brien, "Notes on the Histor 1cal Background of Visual Education," Education, 61:322 February, 1941.

5. Don Carlos Ell1s, and Laura Thornborough, Motion Plctures in Education (New York: Thomas Y. Croweli Company, 1923),p.2.

6. Manson MIIner Brien, op. c1t., pp. 323-324. 
London Spelling Book" was published. It contained a tree of knowledge and an illustrated alphabet which were used to teach lessons in morals.

Due to the great increase in the printing of books, many of which were sold at lowered rates, the schools relied more and more upon them - In fact so much so that courses of study were later built around specific textbooks. Some outstanding educators at this time saw the danger of too mach verbalism and dependence upon textbooks.

Pestalozzi and Rousseau, representing the naturalist school, taught that the child should learm life by living and preached a "return to nature." Froebel, who put Pestalozzi's theories into practice, believed in developing the senses of sight and touch and employed visual aids in his famous kindergarten.?

Another discovery which furthered the cause of visual aids was that of Tom Wedgwood's in 1802. "He discovered the way to make photographic plates in which the action of light on the plate left a record of the object to which the plate was exposed. However, 1t was not until 1822 that Niepce, a Frenchman, found a method of fixing the pictures so that they would be permanent records."8 This invention was the foremuner of the stereopticon, which was introduced about 1893. Also in 1893 was

7. Don Carlos Ellis, and Laura Thornborough, op. cit., p. 3 .

8. Walter Bradley, Visual A1ds to Education (Unpubirshed Master's thesis, The University of M(chigan, 1937). 
Introduced the kinetoscope, which had been invented by Thomas Edison. The observer viewed the ting pictures as they pessed through a slit in a rapidiy rotating shutter, giving the effect of continuous motion. This kinetoscope was based on a fundamental principle known for thousands of years.

This principle is based on the fact that when an object at which one is looking is suddenly removed, the image remains on the retina of the eye for a fractional part of a second. This is sometimes referred to as defect in vision or persistence of vision. Now when a serles of different still pictures flash before the eye, they seem to have acquired the quality of motion. 9

While the development of the motion picture is new, the Idea bohind it is old. As long ago as $65 \mathrm{~B}$. C., Lucretius in his Rerum Natura wrote of "Images that appeared to move", and Ptolemy, the Greek philosopher, wrote a series of books on optics about $130 \mathrm{~A}$. D., in which he spoke of persistence of vision and described simple apparatus by means of which the phenomenon might be observed.10

The invention of the motion picture projector enabled pictures to be flashed upon the screen. These first "movies" were very short - about ten minutes in length - and were usually vlewed by a small gathering which had convened for this special occasion.

9. Harry ICKown, and AIvin Roberts, Aud10-Visual A1ds to Instmaction (New York and London: MeGra pany, 1940), p. 146.

10. Don Carlos Elils, and Laura Thornborough, op. c1t., p. 6 . 
In one of the early discussions of motion pictures, the story is told of a group which had gathered in one of the small plcture houses to see motion pictures of the ocean waves coming in to the shore. The plctures were so realistic that those who were seated on the front rows actually bolted, causing much damage to the furniture and to others present.11

Even though more attention had been devoted to the development of motion pictures for entertalnment purposes, their educational value was never lost sight of.

The Federal Government was among the first to utilize motion pictures on an extended scale for instruction. The United States Reclamation Service seoms to have been the pioneer among the bureaus at Washington to take up this work, and that bureau exhibited at the Jamestown Exposition 1907 films showing the work of the Government in reclaiming arid lands.

The U. S. Department of Agriculture was soon to follow and was the first branch of the Government to establish a laboratory of its own for the production of educational films. Pictures on plant and animal production, forestry, plant and animal diseases, home economics, dalrying, food chemistry, road building and numerous other subjects covered by the varled activities of the Department were made.12

Although this splendid beginning was made by the

Govermment in the field of educational films, still education lagged behind, for only a few schools utilized them. However, the high cost of projection equipment, the fire hazard present in the thirty-five millimeter film (which was the only one being used at that time) and the lack of

11. Ellsworth C. Dent, The Audio-Visual Handbook TChicago: The Soclety for Visual Education, I939, p. 94.

12. Don Carlos Ell1s, and Laura Thornborough, op. c1t., p. 17 . 
good films for educational purposes may have accounted for many schools not avaling themselves of this medium.

But even up to the present time education has lagged behind in its use of this powerful aid.

According to a recent report on "The Motion Picture in Education", prepared and published by the American CouncII on Education, there are approximatelf 16,000,000 school children attending 82,000 schools which are known to be equipped with electricity. These 16,000,000 pupils are served by 10,000 projectors, many of which are obsolete, and about 10,000 films, the educational value of which is unknown.

Many reasons have been advanced to explain the tremendous gap between the development of the motion picture for the theater and the extent of its use in education. While it is true that in the past five years educational developments have been more rapld and we now stand on the threshold of even more significant advances, it is nevertheless perfectly plain that the schools are far behind the theater in the use of motion pictures.

One of the most obvious reasons for this situation is the fact that theaters are run for profit while the schools are not. A second reason is that schools are conservative. They are slow to buy expensive equipment which they feel is not indispensable to their work. Even though numerous experiments have demonstrated the superior merits and teaching values of motion pictures, yet these experiments have not convinced the educational world of their absolute necessity for carrying on the work of the schools. The film is still regarded as a luxury and not a necessity. A third reason why the schools have falled to keep pace with the theater in the us $\theta$ of fllms is lack of teachers who are trained to use them effectively.13

Reviewing briefly the history of the audio aids

13. Mark May, "Educational Possibilities of Motion Plctures," The Journal of Educational Sociology, November, 1937. p. I5I. 
examined in this study, it is interesting to note that the history of the phonograph also dated back to ancient times.

From Egypt comes the first corroborated account of vocal sounds issuing from a thing without Iife, more than 1,500 years before the beginning of the Christian era. An ancient Chinese book of 2,000 years ago contains a story of a curlous box into which a Chinese prince was supposed to have spoken his message which he sent by a tmasty messenger to his friend. When the friend opened the box, so the legend states, he could actually hear the words which had been spoken into 1t.14

Thomas A. Edison is credited with the invention of the tin-foll cylinder machine in 1877, and five years later, working with a wax cylinder, he produced the machine which later became known as the phonograph. 15

Although many improvements were made, the phonograph, like the motion picture, was used at first for entertainment purposes only. "So far as is known, the first phonograph record was used in a classroom for instructional purposes in 1909, in the public schools of Milwaukee, Wisconsin."16 While schools were slow in adopting this aid, phonographs are now used quite extensively in all schools throughout the United States. Similar to the phonograph, the radio has steadiIy progressed from its first ear-phone sets in use twenty

14. EIIsworth C. Dent, op. cIt., p. 128.

15. Harry McKown, and AIvin Roberts, op. c1t., p. 232.

16. Ellsworth C. Dent, op. c1t., p. 128. 
years ago, to its present "stream-Iined" version found in millions of homes today.

Broadcasting as we know it today had its birth on November 2, 1920 when the returns of the pres1dential election of that year were broadcast from Station KDKA in East P1ttsburgh. So successful was this initial effort that other stations came on the air in rapid succession unt1l 1922 when there were four hundred of them operating. By July I, 1936 the number of broadcasting stations had grown to 656.17

Again education lagged behind in adopt ing this powerful influence for classroom use, but in recent jears many teachers have utilized the radio very effectively in their classroom instruction.

Reviewing briefly the history of the audiovisual ald movement, it will be noted that the use of the concrete and realistic have been prominent in the educational systems of the past.

Examining the present century it will be noted that the teachings of such eminent educators as Dewey and Kilpatrick have caused many teachers to question their philosophies and revise the1r methods of instruction. Dewey's phllosophy, stressing school as a place in which the child lives and learns day by day and not a place in which he is proparing for adult life, has again brought visual-sensory instmaction into the forefront. According

17. John J. Floherty, On the Air, the story of Radio (New York: Doubleday, Doran and Company, 1938), p. 14. 
to Thomas, five cultural forces have caused audio-visual alds to gain in usage. These are:

1. The rapid development of experimental sclence, technical industry, travel, communication, and knowledge of other lands, making a more econom1cal presentation of facts an educational necessity.

2. Rapid urbanization, making it difficult for c1ty and country school children to understand each other's Iife by means of the printed page alone.

3. A rapid enlistment in high schools and evenIng schools of persons having slight literary trad1tion, and therefore largely dependent on perceptual alds for actual learning.

4. The rapid use of educational psychology, with its study of interest, attention, learning, recall, and individual differences, demonstrating the urgent need for new techniques of teaching, especially for backward pupils.

5. A rapid increase in photographic research and invention notably in the fleld of the cinema, leading to the tremendous growth of the motion picture industry, with important consequences for education. 18 
TYPES OF AUDIO-VISUAL AIDS EXAMINED

IN THE SURVEY - THEIR ADVANTAGES

AND IIMITATIONS IN INSTRRCTION 
TYPES OF AUDIO-VISUAL AIDS EXAMINED IN THE SURVEY THEIR ADVANTAGES AND LIMITATIONS IN INSTRUCTION

This survey was based on the following fourteen different types of audio-visual aids - school excursions; objects, specimens, and models; graphs, charts and diagrams; maps and globes; mounted pictures; opaque projector; stereoscopes; lantern slides; fllmstrips; motion pictures; microscope slides; phonograph records; and radio. These fourteen types were selected for the following reasons: (1) the majority of authorities classify them as audio-visual aids; (2) these alds are avallable to the Loulsville teachers. The writer, therefore, deemed It pertinent to include a chapter stating the values and limitations of each of the above types in teaching. As there are some adventages and principles besic to the successful use of all audio-visual aids, a resume of these will be submitted herewith.

\section{Advantages}

Aud10-v1sual alds -

1. Are easy to understand and master because they are concrete. 
2. Make accessible to the learners that which is inaccossible.

3. Provide an economy of time as they simplify the teaching processes and reduce the explanations made by the teacher.

4. Arouse very keen interest and ald in developing desirable attitudes on the part of the learner.

5. Usually stimulate the learner to further activities.

6. Enrish the whole teaching program. ${ }^{1}$

While audio-visual alds contain the advantages Iisted above, yet there are certain important principles to be considered in their use.

\section{Principles of Use}

Audio-visual aids -

1. Must be "tools to learning", the means to an end and not the end itself.

2. Must be carefully selected by the teacher to serve a specific function in her daily instruction.

3. Must be carefully prepared by the teacher to ensure greatest value in their use.

1. Harry McKown, and AIVIn Roberts, Aud1o-VIsual A1ds to Instruction. (New York and London: KcGraw-Hill Book Company, 1940). pp. 20-36. 
4. Must be appropriate to the age experience of the pupils.

5. Must be integrated with the curriculum or the course of study to be most effective.

6. Must lead to further learning situations discussions, experiments, dramatizations or readings •

7. Must bo varied in their use as erch ald serves a definite purpose.2

Having cited the advantages and principles peculiar to all audio-visual alds, a more specific explanation follows.

\section{School Journey}

The school journey is the most valuable of all visual aids as it takes the child directly to the learning situation. Here he sees for himself how the evening paper is printed, how milk is pasteurized, how baseball bats are manufactured, or dozens of other similar experiences. There are several kinds of trips avallable to Louisville teachers - excursions to industrial plants, visits to parks, journeys to civic institutions, trips to observe some physical feature of the earth (rivers, hills, clouds, stars), and trips to study one's community. 
In fact a study of one's community is verry beneficial as it quite often deepens the social understanding of the pupil, which may ultimately contribute to the improvement of living in his locality. Harap makes this significant comment:

It seems safe to predict that the emerging curriculum will be concerned with the improvement of living in the community. The pupil will have increasing contact with his natural and social environment. The whole community will serve as a laboratory for learning. The school will be a community of children within a larger social comminity, and 1ts program will touch every phase of group experlence - home life, government, industry, commerce, recreation, transportation, communication, and organized social lifo. The schogl of the future will indeed be a community school.3

In planning a school trip much preparation is necessary on the part of the pup1ls and teacher.

Regardiess of the nature of the excursion, advance preparation, the proper attitude during the trip, and carefuliy prepared reports are important essentials. The safety of the pupils must be given consideration. The pupils should have clearly in mind the purpose of the trip, the general plan to be followed, their individual responsibilities for the success of the trip, and such preperation as is necessary to guide them in their observation. Details should be so planned that the focal point of every pupil's attention will be on the thing to be learned during the specific parts of the trip where learning should take place.4

To be of most value to the pupils, the journey

must be followed by a discussion, experimentation, or some

3. Henry Harap, "scope of an Effective School Program for Ut1lizing Community Resources," Elementary School Principal, Elght eenth Year Book, July, 1939, p. 457.

4. CIine M. Koon, School Use of Visual Alds (Weshington, D.C. U.S. Dept. of the Interior, Dept. of Educet Ion, 1938). p. 24 . 
other learning situation. The advantages of the school journey can be stated thus:

1. The journey presents subjects being studied in their natural setting.

2. It provides concrete evidence which is necessary for pupil understanding.

3. It correlates the school subjects with actual Iifo.

4. It develops keenness of observation.

5. It abolishes the formal schoolroom atmosphere and utilizes the socialized lesson attitudes insterd.

There are several disadvantages, howerer, in takIng a group of children on a trip, some of which are:

1. Inclement weather often prevents or postpones a trip.

2. Lack of transportation facilitios hinders journey.

3. Children are not always able to see specific items visited because of too large a number on the trip, or lack of cooperation on the part of personnel at places visited.

4. The guide is often not trained to talk to 
children in terms they are able to comprehend.

5. Sometimes there is so much noise from the machinery that the guide cannot be heard by the children.

6. Too much time is consumed in getting to and from the objective.

7. Teachers usually are unable to go on journeys during school time and often cannot make trips after school hours.

However, the learning which results from a successful trip outweighs the disadvantages to such an extent that this medium should be used extensively. Objects, Specimens, and Models

objects, specimens, and models are other media which, when properly used, give declded value to educetion as they provide concrete experiences instead of abstract. Dent defines these three alds as follows:

The object is the thing 1tself - plant, fruit, vegetable, bird, animal, etc. - that can be brought into the classroom for study. The specimen is a sample, a part intended to show quality, one of several things which represent all - for example, a plece of coal, wood, cloth, etc. The model is a small-size representation, as for example a bullding, engine, heart, lungs, globe, etc. 5

There are three distinct advantages in using these aids in instruction, viz.

5. Ellsworth C. Dent, The Audlo-VIsual Handbook Ch1cago: The Society for Visual Education, 1939. p. 26. 
1. An object, specimen, or model gives the pupil first-hand experience with the item.

2. By collecting and handling of these materials children gain an understanding of their characteristics and uses.

3. These alds can be very useful in helping the child to understand the elements of his environment and the relationship of these elements.

The Iimitations of these aids, as stated by Mckown and Roberts, are:

1. They are out of their functional relationships.

2. They are larger or smaller than the orig1nal.

3. They are oversimplified. 6

Just how valuable these alds are in teaching will, of course, depend on the teacher's proper use and choice. Graphs, Charts, and Diagrams

Graphs, charts, and diagrams also have specific values in education if properly selected and presented. Their main advantage lies in the fact that they very clearIf illustrate quantitative data - data which are usually difficult for the child to understand. A simple line, 6. Harry Mckown, and AIvin Roberts, op. c1t., p. 59. 
circle, bar graph, chart, or diagram enables a pupil to comprehend statistical information quite readily. These aids are very valuable for this type of informetion. The limitations of these aids, as noted by Dent, are:

1. The chart frequently is not large enough to be seen by all.

2. The chart, graph, or diagram is limited in the scope of material which can be presented by means of 1 t.

3. Unless students have been trained how to read charts, graphs, and tables the instmactor will have to spend considerable time in explanation.7 Maps and Globes

Since maps and globes are practically considered as necessities in teaching, many schools have been furnished with these aids.

Maps, as we shall consider them here, are graphic representations of the surface of the earth, or particular sections of 1t, showing the relative size and positions of the parts represented. Directly and indirectly maps reveal an enormous amount of information - sizes, shapes, and locations of areas, distribution of peoples, land, water, animal and vegetable Iife, climate, economic resources, and othor natural phenomena, and the associations of thes $\theta$ many elements.8

7. EIlsworth C. Dont, op. c1t., p. 31.

8. Harry Mckown, and AIvin Roberts, op. c1t., pp. 71-72. 
The main advantages in using maps are:

1. Maps enable the pupils to comprehend more readily abstract concepts of size and direction.

2. Maps reduce the scale of areas and distances so that what is otherwise intangible becomes meaningful.9

The globe is a type of map more accurate than the flat map because it actualif resembles the earth in shape, and water and land masses are shown in proper relative sizes and positions. When a spherical or three-dimensional representation is translated into a flat or two-dimensional map distortions are inevitable.10

Besides this main value stated above, the globe can be used as follows:

1. To teach the movements of the earth.

2. To teach changes in time.

3. To teach the meaning of longitude and latitude.

Though maps and globes are of untold value in Instmaction, there are several factors to be considered in their use. These are:

1. The symbols and terms used on maps and globes are sometimes so difficult that pupils need much training in their use.

2. Since wall maps and globes can be seen and

9. Charles Hoban, Charles Hoban, Jr., and Samuel Z1sman, V1sualizing the Curriculum (New York: The Cordon Company, $1937) \cdot \mathrm{p} \cdot 22 \%$.

10. Harry McKown, and Alvin Roberts, op c clt., p. 72. 
studied by only a few children at a time, they are most effectively used in small groups.

\section{Mounted Plctures}

Inasmach as mounted pictures are so plentiful and readily avaliable, a large number of teachers utilize this medium in their teaching. Teachers recognize the benefits gained in using this a1d, perhaps more so than obtains in using other alds. McKown and Roberts list the following values of flat pictures:

1. They are so real and vivid.

2. They are easily available.

3. They are convenient to use.

4. They are inexpensive.

5. They can be used repeatedly. 11

Although a great number of teachers employ pictures very extensively in their instmuction, many err in the method of using them by:

1. Using too many plctures at a time.

2. Using pictures that are poor in quality.

3. Using pictures unsuited to the mental development of the child.

4. Using pictures not adapted to the specific situation.

11. Ib1d., p. 104. 
However, if teachers will carefully take the time to select, mount, and file pictures, their efforts will be repaid manyfold by the advantages gained in the use of this aid.

\section{Stereoscopes}

Although stereoscopes were used in the home for entertainment as far back as 1893, they have not been used extensively in the schools, probably because so few teachers realize how valuable they are as a teachIng a1d. These are the only pictures which give depth, thus imparting to the children a feeling of reality which is lacking in the other visual alds. In fact this sense of reality is so vivid that the writer has often heard such remarks as these from children studying stereographs: "That man w1ll fall off the cliff if he takes another step." "We feel like we can touch those trees and flowers." The important advantages of stereoscopes are:

1. They present a more realistic view than is given in any other type of picture.

2. They are extremely valuable for individual instruction. (However, many teachers regard this usage as a detriment in that too much time is consumed in this manner.) 
No doubt with the advent of more group and individual instruction in the public schools, teachers will probably recognize the real value of stereoscopes and will become more skilled in their use.

\section{Lantern Slides}

Lantern slides is another medium which is beneficial to education. These slides usualiy are made of glass upon which a picture is printed. The slide is then projected upon a screen and can be used very effectively for group study and discussion.

The advantages of lantern slides are as follows:

1. Lantern slides present material which is Intended to clarify or supplement subject matter, or to make instruction on units of work more meanIngful.

2. Lantern slides may be left on the screen for any desired length of time.

3. Lanterm slides may be used quite successfully in a room which has not been darkened thoroughIy.

4. Lantern slide projectors are very easy to operato.

The limitations of lantern slides are: 
1. Due to the fact that lantern slides are made of glass, they are easily broken.

2. Lantern slides require adequate space for filing or storing.

3. Lantern slides are more expensive than some other types of visual aids, such as filmstrips, mounted p1ctures, or stereographs.

\section{Opeque Projector}

The opaque projector is an instrument which, by reflection, projects pictures, post cards, maps, and other plctorial material.

Materials for use in it may be collected from mundreds of sources, including books, magazines, post cerds, travel bulletins, catalogs, or nearly anything which has in it an illustration worthy of class consideration. Ordinary typed material, drawings, diagrams, and graphic presentations of all kinds may be used in it quite satisfactorily.12

There are three outstanding features of the opeque projector which cause it to be invaluable in classroom instruction. They are:

1. The opaque projector will project almost anything to a screen for group study.

2. Even colored pictures are reproduced accurately by the opaque projector.

3. Beceuse of the abundance and avallability 
of material which can be used satisfactorily in this Instrument, the opaque projector is quite economical.

Although the opaque projector can claim the above advantages, it has the following limitations:

1. Its greatest limitation is that a thoroughIy darkened room is necessary for projection.

2. The projector is rather large and thus is difficult to handle.

It will be noted, from the above, that these two limitations are trivial compared to its many advantages, and a skillful teacher doubtlessly w1ll find means of overcoming thom.

\section{F1lmstrips}

F1Imstrips serve about the same purpose as

lantern slides, for they can also be used very effectively

for discussion or study with a class or group.

It differs from the glass lantern slides by printing the pictures in series on $35-\mathrm{mm}$. film. The f1lm plctures, therefore, are reduced to about $3 / 4^{n} \times 1^{n}$, or $1^{n}$ to $1-1 / 2^{n}$ in $s 1 z \theta$, and their cost, weight, and storege space are reduced correspondingly. Although the slides are in fixed series, slight projector adjustment makes it possible to show the pictures in any order which may be desired.13

Filmstrips have many qualities which make them 
very desirable aids in teaching, some of which are:

1. The machine is very light in weight and may be easily moved from room to room.

2. Filmstrips also are light in weight.

3. Filmstrips require a minimum of space for storage.

4. Both the projector and filmstrips are comparatively inexpensive.

5. Filmstrips are easily obtainable.

Filmstrips have the following limitations:

1. They require a totally darkened room.

2. As the pictures are in a series, they are not so flexible for use as are slides.

Motion P1ctures

One of the newest of the visual aids is the motion plcture, but already it is recognized as one of the most powerful teaching instmuents yet invented. It is the best substitute for the real experience and since many experiences are inaccessible to children, it is indeed a wonderful substitute. But the motion picture should only be employed where motion is necessary inasmuch as a picture of an inanimate object can be studied just as thoroughly by means of a lantern slide, stereoscope, or 
mounted picture. McKown and Roberts state:

The chief function of the motion picture is to depict motion and motion implies continuity. If motion is not an essential part of the representation, a still picture will serve instructional purposes more adequately. Motion may be classifled as observable and unobservable. The motion film very effectively reproduces both. Through motion that is observable to the human eye, complete processes which normally extend over a long perlod of time and which take place in various sections of the country may be recorded on the motion-plcture film and brought into the classroom. This is the only method by which such information can be made avallable for the teacher's use.14

The motion picture can also portray happenings

in nature which are elther too slow or too rapld to be observed by the human eye as they actually occur. For example, the growth of a plant, the blooming of a bud, or the development of a butterfly occur so slowly that it is scarcely noticeable to the human eye. Yet many films portray this action very accurately and vividiy.

Most people are familiar with slow motion pictures and readily realize their value. To be able to soe a fast runner, a football game, or other similar incidents slowed down to such an extent that it can be observed closeIy makes that type of film very effective for a group studyIng this particular movement. Much criticism has been directed against the use of

14. Harry MaKown, and AIvin Roberts, op. cit., pp. 148-149. 
motion pictures in schools, and no doubt it was at first justifiable. But now with the introduction of fine educational films, and the acquisition of correct procedure In their use by many teachers, the motion picture should bocome an established asset in education.

It would appear that far too many teachers use motion pictures as a "picture show", overlooking the fact that the same careful preparation is necessary in their use as when utilizing books, plctures, or other types of audio-visual a1ds.

The chlef advantages of motion pictures as listod by Dent are:

1. The moving picture has the unique advantage of depicting action or behavior, with its irresistible illusion of life and reality. It is however, an expensive visual ald and for that reason should be resorted to only when necessary (I) to show activity, which no other pictorial aid can actually portray, and (2) to provide such vicarlous experiences as may be brought to us because we cannot get them in any other way.

2. The film has proved valuable to scientific workers by enabling them to reproduce processes and 
analyze motion and movements for detalled study. 3. The film has value in presenting popular non-technical phases of the subject to those who have relatively little knowledge regarding it.

4. Beans of the motion picture and the animated diagrem, on $\theta$ can visualize the invisible.

5. The motion picture is very effective in publicity, drives, compaigns for social betterment and similar forms of propaganda.

6. The film is the best visual tool when the continuity of a process involving movement is to be seon.

7. The film is advantageous for purposes of vivid summary or general survey of a broad topic. 8. The film is unique in revealing, for the first time in the history of muman learning, things which are too slow or too fast to be seen by the human eje. 15

Iimitations of the motion picture, as cited by Dent, are:

1. The film with its rapid-fire method of projection mist be stopped, slowed up, or shown a second or third time if any real study and analysis of the 
content is to be achieved.

2. Some moving pictures have a tendency to relegate the teacher into the beckground.

3. Continuity is definitely establishod. This may not fit the teaching plans but is not a serious problem to the teacher who is trained to use motion pictures effectively.

4. F1Ims are per1shable and do not stand wear and tear like some other visual alds.

5. The flim, to be effective in the classroom, should be previewed by the teacher and followed up by definite study. Sometimes the teacher cannot get the film when it is needed most.

6. The flim is used too often as a substitute for, rather than a supplement to, other methods of presentation. 16

These limitations will probably appeax insignificant when It is realized what tremendous influence films have on the lives of children.

\section{Microscope SIIdes}

Microscope slides, whlle somewhat different from the visual alds mentioned previously, also heve a distinct value in instmaction. The microscope is indeed of untold 16. Ib1d., pp. 100-101. 
value in teaching subjects of a scientific nature. A child has a much better conception of blood corpuscles, types of bacteria, or parts of a plant when observed under a microscopo.

The microscope has three unlque advantages which are:

1. It magnifies minute organisms too smell to be seen and studied with the naked eye.

2. Through the use of a microscope a child gains a truer conception of organisms studied.

3. The use of the microscope practically always arouses keen interest and enthusiastic response on the part of the children. The following items may be considered as limitations:

1. Microscope and slides are often too expensive to be purchased for classroom use.

2. To be used most effectively several microscopes are needed for each group.

Phonograph Records

Concerning audio alds the phonograph ranks high in use among teachers; in fact, according to Dent, phonograph records are used more extensively by schools today 
than are any of the other types of audio-visual aids to instmuction. 17 While records are of great help in teaching masic and masic appreciation, they can be successfully employed in many other subjects.

Outstanding advantages of phonograph records are:

1. They can be played whenever needed.

2. They can be played as many times as the situation demands.

3. They can be correlated with a great variety of subjects which make them extremely versatile.

4. They are now being made in unbreakable form.

Two disadrantages of phonograph records are:

1. Most records, especially those owned by schools at the present time, are easily broken.

2. They require ample space for storage. Redio

While the radio is a new-comer in the field of audio aids, 1t, like the motion picture, has a tremendous influence on the IIves of children and adults. The Czechoslovakian crisis, the present news broadcasts of this World War, or the fantastic broadcast from "Mars" eas1ly demonstrate the power radio has to mould or change the thought and emotions of both child and adult. Such 
Important events as the inauguration of the President of the United States or the historic speech of President Roosevelt before Congress on December 8, 1941, should be part of the experience of every child capable of comprehending these broadcests.

The radio is valuable in teaching because of the following features:

1. It is capable of enriching all classroom work due to the variety of worth-while programs on the a1r.

2. It provides splendid opportunities for educating chlldren in the wholesome use of lelsure time.

3. It offers unlimited means for teaching children discrimination and judgment.

The radio is limited in its scope due to the following reasons:

1. Even though a teacher has advance knowledge of the type of program scheduled (masic, art, lecture, or a play) she will st1ll be unfamiliar with the exact treatment of the subject prior to the broadcast. 2. Many radio stations do not furnish manuals for broadcasts, thus prohibiting advance preparation 
on the part of the teacher.

3. Teachers are not always able to arrange schedules so as to hear broadcasts.

4. In some instances reception is too poor to permit a class to listen to broadcast.

In order to overcome these limitations many schools are purchasing radio recordings, better known as transcriptions. These transcriptions can then be used by a teacher whenever she wishes and played as often as she desires. As teachers realize the values to be gained through using the radio in instmaction, this medium no doubt will be used more extensively.

It is hoped that this chapter has conveyed to the reader a better understanding of the different types of audio-visual alds avallable to the teaching profession. As numerous scientific experiments have been made proving the value of audio-visual alds in instruction, the writer deemed it pertinent to include a chapter dealing with this phase of the subject. 
APPRAISAI OF AUDIO-VISUAL AIDS BASED

ON SOME OUTSTANDING RESEARCH 


\section{APPRAISAL OF AUDIO-VISUAL AIDS BASED \\ ON SOME OUTSTANDING RESEARCH}

Although visual aids date back to prehistoric times, yet it has boen only in recent years that experiments heve been conducted scientifically to determine tholr true value. This chapter deals with some of these experiments which, in the writer's opinion, prove the real worth of audio-visual a1ds.

Experiment of Harper and Otto to Evaluate Graphs in Instmiction

Harper and 0ttol carried on an experiment to evaluate graphio instruction materials.

\section{Problem:}

The experiment attempted to measure the value of instmaction in the interpretation of simple graphs.

\section{Procedure:}

The experiment was carried on in the public schools of Wilmetto, Illinols during February and March 1933.

Four separate experiments were carried out involving the teaching of geography in the fifth and s1xth grades over a six weeks ' perlod. Threo of the experiments had two control groups and one experimental group. One experiment had one control

1. R. 1. Harper, Henry J. Jtto, "In Evaluation of Graphic Instruction Mater1als," Thirteonth Yearbook, Nat1onal Elementary Principa 1, Juñe 1934; pp. 228-237. 
and one experimental group. A total of 365 pupils were involved in the experiment.

The control and experimental groups wore plcked on the bas is of median intelifgence scores. In no caso was there a signiflcant difference in the median gcores between the group in any one exporiment. 2

The fifth grade pupils studied a unit on the geography of southosstern United States; the control group covering this material as usual, 1.e., using textbooks, discussions, reading and reports, while the experimental group bad use of all the abovo plus olght oon supplementary graphs. The grapho wore all relat od to tho study and were presented at the most opportune times. The sixth grade experiment was carried on in the same manner except that these chlldron were studying the geography of Germany.

Three sets of tests were used to measure the outoomes of instruction. A record was also kept of the time required to teach the unit to oach group in order to determine if graphs lengthened or shortened the teaching time of a unit.

\section{Results:}

The results of the tests showed that three of the experimental groups improved more than did their 
respective control groups, while one experimental group did not impro ve at all.

The results of this study seom to indicate that the graph pcesents a different kind of information than is generally presented in the textbooks in geography. The texts used in this study seldom discuss od the relative importance of various factors, the type of information which the graph presents.

When in the course of geography study it is found desirablo to present this type of comparat1vo information, it would seem that the graph is the best median to use. Children in the fifth and sixth grades can derive this typo of information from tho graphs readily and aro quite as moch interested in graphs as they are in pictures or othor typos of visual matorial. Very little timo need bo apent in instruction in the uso of graphs.3

As was statod in Chapter III, the stereoscope has cortain distinct advantages. By mogns of it an individual is ablo to estimato distance and depth.

Experiment of J. J. Wober to Evaluato Stereographs in Instruction

J. J. Weber ${ }^{4}$ made an experiment which attempt od to measure the value of depth in the stereograph.

\section{Problem:}

A. Has the factor of stereoscopic perspective any educational value?

B. Does the element of oolor add to this value?

c. How does this value vary with the intelligence

3. IbId., p. 236

4. J.J. Weber, Vigual A1de in Eduoation (Valpara1so, Ind1ana: Valpara1so UnIversity, 1950), pp. 120-124. 
of the pupil?

\section{Procechre:}

The procedure involved the showing of a sorles of scenes with and without perspootive and carefully noting the observation span in seconds. (By measuring the pupil's voluntary observation span, a falrly good notion of tho appeal that any object or activity holds for him is recorded.)

\section{Results:}

The factor of perspective lengthened the observation apan by elght percent, on the avorage, and the addition of color increased it an additional six porcent. It was also found that stereoscopic perspective varied inversely with the intelligence of the pup1l, although tho correlation was far from close. Obviously the correlation is more with a factor that enters into intelligence, namely, exporience.5

Experiment of J. J. Weber to Evaluate Lantern SIIdes in Instruction

J. J. Weber 6 also mado an interesting and $81 \mathrm{~g}-$ nificent experiment using lantern slides. He folt that "plotures aro substitutes for actual visual situations; and obviously lantern slides, along with languago, should provide a highly effective method of instmaction." 7

Problem:

This experiment was organized to determine how

5. Ib1d., p. I21.
6. Ib1d.' pp. 133-135.
7. Ib1d., p. 133.


the lantern slide thus functions as a visual ald.

Procochre:

The experiment involved the "double-cheak"

method, inlch was a combination of the rotation and

equivalent-group method.

The instructional material consisted of two lessons and two sets of lantern sildes - one set on the manufacture of glass bottles and the other on manila homp. In tho first experimental unit the lesson on glass was taught to the "A" group of subjects with the ald of lant orm slides, while to the "B" Broup of aubjects it was taught without the slides. In the second unit the lesson on hemp was taught to tho "A" group unalded and to the "B" group alded this time.

Four types of tests were used to cheok up on the results - freo-recall written report, completion tests, jes-no test, and concerled test.

\section{Results:}

The tests revealed that the us o of lantern

sildes Increased the scores of the children considerably. The "alded" lessons were also loamed more thoroughly than the "unalded" ones.

Experiment of M. Meador to Evaluate Plctures in Instruction

Meador ${ }^{9}$ also contributed an important experiment to the fleld of visual alds.

8. IbId., pp. 133-134.

8. Mildred Meador, "Are Pictures an Effective A1d in the Teaching of Goography ?" Educational Method, Norember, 1931. 


\section{Problem:}

A. To determine the real value of plctures as an effective ald in teaching.

B. To determine the method of presentation best adapted to secure the greatest gain in kmowlodge.

Procoduro:

Ten countries were selected for study, and a film contalining botween twenty to thirty fiews was used as each country was studied. Thre日 schools wore selected for the experiment, uaing, however, only fourth, fifth, sixth, and seventh grado children.

In one school, deslgnated "A", the lessons were taught verbally without plctures; in another school, designated "B", films were shown but discussions were discouraged; and in a third school, designated "C", the films were shown and the discussions were based entirely on the pictures.

Each class was given a test bofore the exper1ment began, another at the ond of the experiment, and a third test was administered one week following the experiment.

\section{Results:}

School "A" gained less than elther of the other 
schools. The retention showed by school "A" at the end of the weok was less than in sohools "B" and " $\mathrm{C}$ ".

School "B" gained more after the lesson than school "A" but $108 \mathrm{~s}$ than school "C". Sohool "B's" loss of retention was not so great as in school "A" but greator than in sohool " $\mathrm{C}$.

School "C" showed a greater gain after the lesson than school "A" or school "B". school "C" showed a gain in retention at the end of the week while both other schools shored a 1088.

Neador conoluded that pletures ald in the teaching of geography in the elementary sohools.

Experiments of W.W. Charters and Others to Evaluate Effect Yotion Pletures Have Upon Youth

Although the other experiments included in this thesis are concerned with classroom activities, jet the findings of W. W. Charters 10 and his comorkers regarding motion plotures and jouth are so significant it was folt desirable to Include a summary of them here.

The Motion Picture Research Counoil sponsored this thorough investigation in order to determine just what effect motion plotures were having upon jouth. only commerclal fllms produced by Hollywood for entertainment

10. W. W. charters, Lotion plotures and youth, 1 summary (Now York: The racmilian Company, 1933). 
purposos were used. This study was subsidized by the Payno fund and was carried on for a perlod of four years, 1929 - 1932 inclusive. Even though these experiments omployed "entertainment" films, jet the results proved that such films do exert a tremendous influence on the lives of chlldren, a fact which mast be recognized by oducators at all timos.

\section{Problem:}

To disoover what effect motion pictures have upon youth, stressing the following:

A. How much information do children acquire from "movies"?

B. Do "movies" change attitudes of chlldren?

C. Do "mories" stimulate the emotions of children?

D. Do "movies" affect the patterns of conduct of oh1ldron?

\section{Procedure:}

In order to answor these questions, investigations were carried on by different oducators, involving thousands of chlldren. Careful statist1cal techniques were ut1lized throughout all the investigations.

Results:

A. Children, even those of the early age of 
8 soo half the facts in a picture and remember them for a surprisingly long time.

B. A single exposure to pleture may produce a measurable change in attitudo.

C. Bmotions are measurably stirred as the scenes of a drama unfold and this excitement may be recorded in deriations from the norm in sleep patterns, by visiblo gross evidences of bodily movement and by refined Intermal responses.

D. They constitute patterns of conduct in daydreaming, phantasy, and action.11

Motion plotures, as reverled by these studies, are a potent medium of education.

Rxperiment of Wood and Freeman to Evaluate Motion P1otures in Instruction

Other educators rere also realizing the power of motion pictures and decided to measure their value by experiments in the classroom. Wood and Freoman ${ }^{12}$ wero two of the ploneers in this field, and although their axperiment was conduct od fourteon yoars ago, it is st1ll considered a classic. Authoritios on audio-visual alds at the present time still consider it one of the most signiflcant oxperiments over mado. For that reason it is

11. W. W. Charters, op. c1t., p. 60 .

12. Ben Do Wood, Frank Froeman, Mot 1on Plotures in the Classroom (Bos ton: Houghton uifei in Compan, I9zo). 
Included in this study. This experiment was conducted in 1928.

Problem:

A. Can films be produced which are correlated with standard courses of study?

B. Can the teaching value of these films when used to supplement the usual pedagogical devices of the teacher in the classroom be measured?

c. Is the educational value of the contributions of the films sufficient to justify the expenditure required to make them a regular part of the equipment of the schools?

\section{Procedure:}

The experiment was conducted in ten large city school systems - 11,000 children participating. Ton 11lms In geography and ten films in general science were used. These fllms were especially produced for this investigation by the Eastman Kodak Compans.

Classes in which the films were used were compared with classes which did not have the advantage of this device. The outcome of the teaching was measured by objective and essay teste.

Results:

In both geograph and general science the film 
Instructed groups were superior to the non-film groups, according to the statistical ovidence obtained from the testa.

\section{Fxperiment of Knowlton and Tilton to Evaluate lotion Plotures in Instruction}

Another famous experiment conducted about the same time was that by Daniel Knowlton and Warren Tilton. 13 This experiment is also considered highly significant by even present day authorities, and therefore hes been included in this study. In this experiment ten f1lms, known as the "Yale Chronicles of American Photoplays" were used.

\section{Problem:}

The experiment was conducted to measure:

A. The amount of historical knowledge possessed by the pupila.

B. The pupils' appreciation of the subject matter of history.

C. The pup1ls' power to retain what had been

learnod.

D. The pupils' greater interest in the subject. Procedure:

The experiment was conducted in the Junior High School, New Haven, Connect 1cut. The ten photoplays were of Instruction in History w1 th the Aid of the Photoplay," The Historicel Outlook, 20 : 167-179, 229-239. 
used with the experimental group and the results obtained were compared with those secured with regular class instruction.

Modern objective tests were prepared and administered to measure the contrasted methods of instruction. These tests were given at the beginning of the experiment, at the end of the experiment, and three months after the experiment was comploted.

Results:

The experimental group, as a whole, made about a nineteen porcent greater gain than did the control group.

Delayed recall tests revealed that the experimental group had learned more, forgotten more, and still retained more than the control group. The forgetting was ohiefly in the category of time concepts.

Th1s statement of Knowlton's, quoted by Weber, is quite significant:

However inherently effective the photoplays may be - and the evidence submitted here indicates the potentialitios of such material - it will only attain 1ts highest degree of effectireness when accompanied by good teaching, basod upon an appreciation of the real goal to be atteined and of the capacity of this material to contribute to its attainment. The teacher has at her command an instrument which, as these results indicate, will go far 
toward economizing her time and effort and stimelating her pupils to secure those ablding values inherent in this vital subject.14

Experiment of C. Mead to Evaluate

Different Procedures in the

Us $\theta$ of F1Im in Instruction

While these first experiments were conducted

primarily to prove the value of motion pictures over verbel instruction, later experiments were made to determine the best methods of presenting motion plotures in classroom instmetion. Such an experiment was conduct ed by Mead. 15

\section{Problom:}

To determine the relative merits of a "taught"

lesson, a film lesson, and a "taught" and film lesson. Procodure:

Children in the third, fourth, fifth, and sixth grader wore taught by all three methods. In the "taught" lesson the teacher used the question and answer method; in the film lesson the children viewed the film without and coment or suggestions; and in the film and "taught" lesson the teacher had mach preparation and discussion before and after viewing film.

14. J. J. Wober, op olt., p. 168 .

15. Cy rus D. Mead, "VIsural v8. Teaching Method - An Exper1ment," Educetional Administration and Supervision, 13: 505-518, November, I92\%. 


\section{Results:}

The "taught" plus film lesson seemed to be best, although oven the viewing of a film without discussion proved better than the usual textbook lesson, as it was four times out of seven better than fust the "taught" lesson.

Fxperiment of J. J. Weber to Evaluate F1lms in Instruction

Weberit conducted another experiment which is worthy of note.

\section{Problem:}

This experiment attempted to test the value of instmact Ional f1Ims.

\section{Procedure:}

Approximately six mundred $7 B$ pupils were involved in this experiment. One group was instructed orally by the teacher; a second group studied the lesson from the printed page; a third group had the lesson depictod by a fllm; and a fourth group viewed the f1lm under the oral guidance of the teacher. Tests followed each method of instruction.

\section{Results:}

The lowest a verage scores were made by the first 16. J. J. WObOr, Op. C1t., pp. 151-152. 
group - those instructed orally by the teacher; those in the second group, who studied alone, ranked next; the third group - those who only viewed the film - ranked next; and the highest scores were obtained by those who viewed the film under the direction of the teacher.

Experiment of Rulon to Evaluate Sound Motion Pictures in Instruction

All these experiments were made with silent films but with the introduction of sound films new problems were presented. Rulon ${ }^{17}$ was among the first to conduct an experiment employing sound films.

Problem:

To measure the educational value of the sound motion picture in the teaching of general science in the ninth grade.

Procedure:

Three groups of chlldren, rather evenly balanced mentally, chronologically, and in achierement in general sclence, were used. One group was taught by the textbook method; the second group used the textbook and the films; and the third group was utilized for measurement purposes only. Tests were administered to all groups; however, since the third group recelved no instruction their

17. PhIIIIp J. Krilon, "The Sound PIctures in Sclence Terohing," Harvard Studies in Education (Cambridge: Harvard University Pross, 1933, vo1. 20). 
scores were considered as zero in respect to instmetion. Tests were alo0 given three and one-half monthe following the experiment.

\section{Results:}

According to the findings of Rulon, the touchIng technique omploying the sound motion film was twenty percent more effective from the instructional standpoint than the usual unalded lesson. According to the tests given after the experiment, the sound film group retained thirty-elght percent more than those taught by the textbook method.

Experiment of Arnopiger to Evaluate Sound lotion Plotures in Instruction

The oxporiment conducted by Arnspiger ${ }^{18}$ in 1932

is very well known.

Problom:

To compare the effectiveness of sound pictures In general science and music with the usual mothods of classroom instruction.

\section{Procedure:}

Fifth and seventh grade pupils were used - the control groups boling taught by the usual methods while the experimental groups were given three showings of each sound

\section{Varnoy C. Armspiger, Yeasuring the Ef fect Ireness or Sound Plctures as Teaching Alds TNe York: Teachers col- Iеge, Columbia Uñ versity, I933).}


f1im along wth oach unit. Objective tests were used before the experiment, following each unit, and four weoks after the conclusion of the experiment.

\section{Results:}

According to the tests Arnspiger concluded that those children taught wh the ald of sound plctures mado greater gains than did those chlldren taught by the usual mothods. The results of the tests also showed that sound plotures de distinct contributions to the learning of pup1ls of both $10 \mathrm{w}$ and high intelligence lovels. The average recall test gains over the inltial test wero greater for the experimental groups than the control groups in overy unit of study.

Experiment of Krasker to Evaluato Different Procedures in the Use of Films in Instruction

In recent years many experiments have beon made to test the advantages of different methods of utilizIng sound or silent films in instruction, such as (1) showIng the film twice to a group - the first time without comment and the second time for discussion and study; or (2) stopping the film as it is being show to answer questions or mak comments; or (3) showing films in auditoriums to largo groups; or (4) utilizing films in tho classrooms with 
smaller groups.

Along these lines the experiment by Krasker ${ }^{19}$

was quite significant.

Problems

To Investigate:

A. "The relat1ve effectiveness of the IIntermittent (stop-start) Uethod' of flim tochnique with regular size classroom groups, as compared with largo size or auditoriun groups ."

B. Nhe comparative efficiency of film lessons with the 'Hon-Preparation Yethod' and film lessons with the IPreparation Kethod'."20

Procedare:

About 800 elghth and ninth grade students wero used in the experiment which extended over a period of three years. Six allent and two sound flims, all dealing with general science, were utilized. Objective testa were employed to measure the progress of the children.

Results:

The author concluded from his studs (I) that small groups progress more than large groups or groups in auditoriums; (2) the ecucational motion picture proved to be an effective instructional device for increasing

\footnotetext{
19. Ibrabam Kragker, "I CFIt1cal hralys 18 of the Use of Educational Motion Plotures by Two Mothods," Educational Screen. September, 1941.

20. Ibid., pp. 305, 313.
} 
factual learning; and (3) one of the present common practices of using educational motion pictures by merely showIng the film without preparation of the class for the study of the motion picture is not an effective method.

Experiment of the W1sconsin Research Committeo to Evaluate Radio in Instruction

In the field of audio alds an experiment was conducted by the Wisconain Research Committeo ${ }^{21}$ as follows:

\section{Problem:}

To test the value of radio in teaching current events and masic in the classroom.

\section{Procedure:}

Students in the sixth, seventh and elghth grades in fifty schools participat od in the experiment - 25 schools were used as experimental and 25 as control. Both group employed a well known current ovents magazine in thelr study, the control groups using only the magazine whlle the experimental groups had lessons over the radio accompenging their instructions with the magazino. Tests were given to measure the progress of the chlldren. This study also attempted to test the value of masic lessons by radio; however, in this case some of the sohools used in the experiments had littlo or no instruction. Value of Radio in the Classroom," School Life, 16: 104105, February, 1931. 
The "radio music" lessons consiated of four parts: (1) information about music; (2) some masic played without comment; (3) rbJthm exercises in which the radio listeners participated; and (4) the teaching of singing. The results were tested by asking each school in the experiment to make a scrapbook of musiogl information, and by having a professor of masic judge subjectively the offectireness of the terching of rhythmic exercises and songs. Tests were also administered.

\section{Resulte:}

Judging by the results of the tests administered to all classes studying current events, the scores of those groups taught with the assistance of the radio excoeded the soores of those taught by only the magaines.

The scores made by the experimental groups on the masic tests were also highor than those of the control groups. The authors concluded, therefore, that the radio is valuablo in toaching current ovents and masic.

In sumarizing the studies reviewed in this chapter, It wil be noted that audio-visuel alds were quite superior to other forms of instruction in almost every experiment. However, there are always some limitations apparont in all experiments and these proved no exception. 
In some experiments the methods of instruction were not typical of classroom procedures; in some the investigators falled to establish nomel sohoolroom teaching procodaro in their investigations, whilo in others many investigators considered audio-visual alds as mothods of instruction instoad of as alds to be used as a part of instructional pro cedure. 
A SURVEY OF THE AUDIO-VISUAL AIDS BEING USED BY THE LOUISVILLE WHITE FOURTH, FIFTH, AND SIXTH GRADE TEACHERS 


\section{A SURVEY OF THE AUDIO-VISUAL AIDS BEING USED}

BY THE LOUISVILIE WHITE FOURTH, FIFTH, AND SIXTH GRADE TEACHERS

The chief purpose of this study was to invest1gate:

1. The difforent typos of aud10-visual aids being used by the Louls ville white fourth, fifth, and sixth grade teachers during 1940-1941.

2. Which of these alds were boing used most Irequently by these teachers, and why.

3. Which of these a1ds were being used least by these same teachers, and whs.

4. In which 21ds the teachers manifested the most interest.

5. In which aids the teachers desired more information.

6. In what ways the audio-visual aids bost answered their needs in teaching.

7. In what ways the audio-risual alds were a valuable media when supplemented with books in instruction. 
This information was obtained by means of a questionnaire which was sent to $238^{*}$ white teachers of grades four, five, and six in 42 elementary schools. Out of this number, 200 teachers answered the questionna1re. Different Trpes of Aids Being Used of the 200 teachers replying, more of them used maps and globes during 1940-1941 than any other aid. Mounted pictures renked second, charts and diagrams third. The other types, in the order of frequency of use were: objects, specimens, and models; graphs; radio trips to civic institutions; motion pictures; phonograph records; trips to parks; trips to industrial plants; lantern slides; trips to observo physical features of earth; sterooscopes; filmstrips; microscopo slides; and opaque projector. Additional data aro givon in Tablo I.

It w1l be further noted from Table I that only seven alds have been used by 50 percent or more of the Iouispille intermediate teachers. The table also reveals that none of the alds requiring oquipment are used as extensively as those alds not requiring mechanical equipment. Extent of Use of Audio-Visual A1ds According to Table II mape and globes were used many teachers ha mixed divisions as $4 A-5 B, 5 A-6 B$. 
TABLE I
USE OF AUDIO-VISUAL AIDS BY TWO HUNDRED
IOUISVILLE WHITE FOURTH, FIFTH
AND SIXTH GRADE TEACHERS

\begin{tabular}{|c|c|c|c|c|}
\hline Alds & $\frac{\operatorname{set} u}{\text { Using }}$ & $\frac{\text { a. Number }}{\text { Not Using }}$ & $\frac{P e}{\mathrm{U}_{B} \operatorname{lng}}$ & $\frac{\text { reont }}{\text { Hot } 0 \operatorname{sing}}$ \\
\hline Maps and Globes & 198 & 8 & 96 & 4 \\
\hline Mounted P1ctures & 184 & 16 & 92 & 8 \\
\hline Charts and Dlagrams & 164 & 36 & 82 & 18 \\
\hline $\begin{array}{l}\text { Objeots, Spocimens, } \\
\text { Models }\end{array}$ & 146 & 54 & 73 & 27 \\
\hline Graphe & 144 & 56 & 72 & 28 \\
\hline Radio & 140 & 60 & 70 & 30 \\
\hline $\begin{array}{l}\text { Trips to Civie In- } \\
\text { stitutions }\end{array}$ & 100 & 100 & 50 & 50 \\
\hline Mot1on P1ctures & 96 & 104 & 48 & 52 \\
\hline Phonograph Rocords & 80 & 120 & 40 & 60 \\
\hline Trips to Parke & 60 & 140 & 30 & 70 \\
\hline $\begin{array}{l}\text { Trips to Industrial } \\
\text { Plant }\end{array}$ & 36 & 164 & 18 & 82 \\
\hline Ianterm SIIdes & 28 & 172 & 14 & 86 \\
\hline Trips to Observe Nature & 28 & 172 & 14 & 86 \\
\hline St oreos copes & 24 & 176 & 12 & 88 \\
\hline F1lmstrips & 22 & 178 & 11 & 89 \\
\hline M1cros cope si1des & 12 & 188 & 6 & 94 \\
\hline Opaque Projootor & 0 & 200 & 0 & 100 \\
\hline
\end{tabular}


often ${ }^{1}$ by 81 percent of the teachers, some ${ }^{2}$ by 15 percent and never by 4 percent. The fact that most schools are equipped with maps and globes and that the majority of teachore are familiar with these alds probably accounted for their widespread use.

Table II further reveals that 64 percent of the teachers used mounted pictures often, 28 percent used them some and 8 percent never used them at all. The accessiblilty of many pletures and thelr comparative low cost no doubt contributed to their general use but, on the other hand, it is quite significant that only 64 percent of the terchers used this medium often whon plctures can be ut1lized advantageous ig in so many ways.

Charts and diagrams were used often by 48 percent of the teachers, some by 34 percent and never by 18 percent, while objects, spocimens, and models claimed 39 percent as constant users, 34 percent using sometimes, and 27 percent as never using. Since teachers are familiar with these alds they seem to provide much of this type in their instruction, though oven these alds are probably not being used as extensively as possible, judging from the percentage claiming to be constant users.

A further examination of the data in Table II

1. The term "often" as us od here signifles dally use or several times a week.

2. The term "somen" as us ed here signifies sereral times monthly. (These terms hereafter w1il carry the same meanings until ot herwise indicated.) 
TABLE II

EXTERT OF USE OF AUDIO-VISUAL AIDS BY TWO HUNDRED LOUISVILLE WHITE FOURTH, FIFTH, AND SIXTH GRADE TEACHERS

\begin{tabular}{|c|c|c|c|c|c|c|}
\hline & $\mathrm{Nun}$ & $\begin{array}{l}\text { cetual } \\
\text { ber Us }\end{array}$ & & Per & ont $U$ & \\
\hline Alde & Often & Some & Bover & often & Some & rever \\
\hline Maps and Globes & 168 & 30 & 8 & 81 & 15 & 4 \\
\hline Mounted Plctures & 128 & 56 & 16 & 64 & 28 & 8 \\
\hline Charts and Dlagrams & 96 & 68 & 36 & 48 & 34 & 18 \\
\hline $\begin{array}{l}\text { Objects, Specimens, } \\
\text { Modeis }\end{array}$ & 78 & 68 & 54 & 39 & 34 & 27 \\
\hline Graphs & 60 & 84 & 56 & 30 & 42 & 28 \\
\hline Radio & 22 & 118 & 60 & 11 & 59 & 30 \\
\hline $\begin{array}{l}\text { Trips to Civic In- } \\
\text { stitutions }\end{array}$ & 6 & 94 & 100 & 3 & 47 & 50 \\
\hline Motion P1ctures & 10 & 86 & 104 & 5 & 43 & 52 \\
\hline Phonograph Records & 12 & 68 & 120 & 6 & 34 & 60 \\
\hline Trips to Parks & 0 & 60 & 140 & 0 & 30 & 70 \\
\hline $\begin{array}{l}\text { Trips to Industrial } \\
\text { Plants }\end{array}$ & 2 & 34 & 164 & 1 & 17 & 82 \\
\hline Lantern SIIdes & 6 & 22 & 172 & 3 & 11 & 86 \\
\hline Tripe to observe & 0 & 28 & 172 & 0 & 14 & 86 \\
\hline Stereoscopes & 4 & 20 & 176 & 2 & 10 & 88 \\
\hline F1lmstrips & 0 & 22 & 178 & 0 & 11 & 89 \\
\hline M1croscopo slides & 0 & 12 & 188 & 0 & 6 & 94 \\
\hline Opeque Projector & 0 & 0 & 200 & 0 & 0 & 100 \\
\hline
\end{tabular}


Indicates that graphs, which rank f1fth in extent of use ( percent of the teachers, some by 42 percent, and never by 28 percent.

The radio was used by 11 percent of the teachers often ${ }^{3}, 59$ percent some ${ }^{4}$, and 30 percent never. It is quite significant to note, according to the figures, that only 1 percent of the Louls ville intermediate teachers used this medium oft on for with the number of portable radios a vallable to teachers it soems incredible that this ald was not more extensively used.

Tripe to eivic institutions ranked seventh -3 percent took this type of trip often ${ }^{5}, 47$ percent some ${ }^{6}$, and 50 percent never. The vast majority of teachers underscored the word "Ilbrary" on the questionnaire, indicating that more of them visited the library than such places as the Post Off1ce, Water Works, Board of Health, or other civic institutions.

It is quite significant that all the rest of the aids examined in this survey were not used by even 50 percent of the teachers (see Table II). The motion picture, for example, was used by only 5 percent of the teachers often, 43 percent some, while 52 percent never used it at

3. The term "often" 28 used here signifles once a week or more.

4. The term "some" as used here signifies a couple of times

5. The term "often" as used here signifies several times a term - a term being five months.

6. The term "some" as us ed here signifies twice a term or less. (These terms hereafter wil carry the same meanings unless otherwise indicated.) 
211 (see Figure 1). Of the 48 percent of the terchers who used this ald, many of these stated that the films shown to their classes were those brought in by outside agencies such as the Dairy Council or Mraffic Division.

\section{Expressed in Percentages}

$\begin{array}{lllllllllll}0 & 10 & 20 & 30 & 40 & 50 & 60 & 70 & 80 & 90 & 100\end{array}$

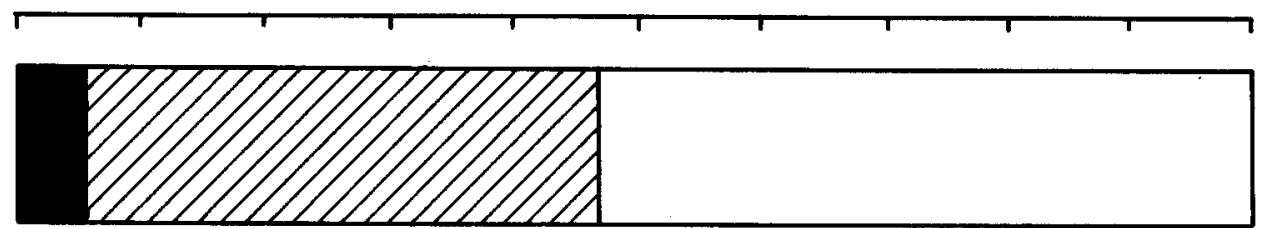

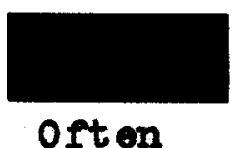

Oft on

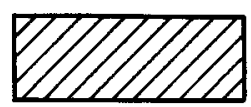

some

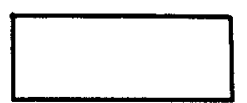

Never

F1gure 1.- Extent of use of motion plctures by Loulsvilie white fourth, fifth, and sixth grade teachors.

In order to determine more accurately how many teachers were using films of their own cholce (not incluaIng those films brought to the school by other agencies), the writer studied the records of Mr. R. E. Daugherty, assistant superintendent in charge of instructional supplies. These records revealed that only six schools, totaling about forty intermediate teachers, used the motion pioture projectors during 1940-1941. 
The investigator was also informed that only one elementary school has its own projector which is in good condition; two other schools have projectors but both are unusable. Inasmach as the good projector is a sl lent one, the school owning it was among the $81 x$ requisitioning the sound projectors from the Board of Education curing 1940-1941.

Therefore, it can be determined that rery fer Louls vilie white fourth, f1fth, and sixth grade toachers are securing films to meet the needs of their classroom instruction. The reasons lis ted by the teachers for not making more use of motion plctures and other mechanical alds w1l be presented later.

Phonograph records were used often by 6 percent of the teachers, some by 34 percent, and never by 60 percent (see F1gure 2). Since the majority of schools have

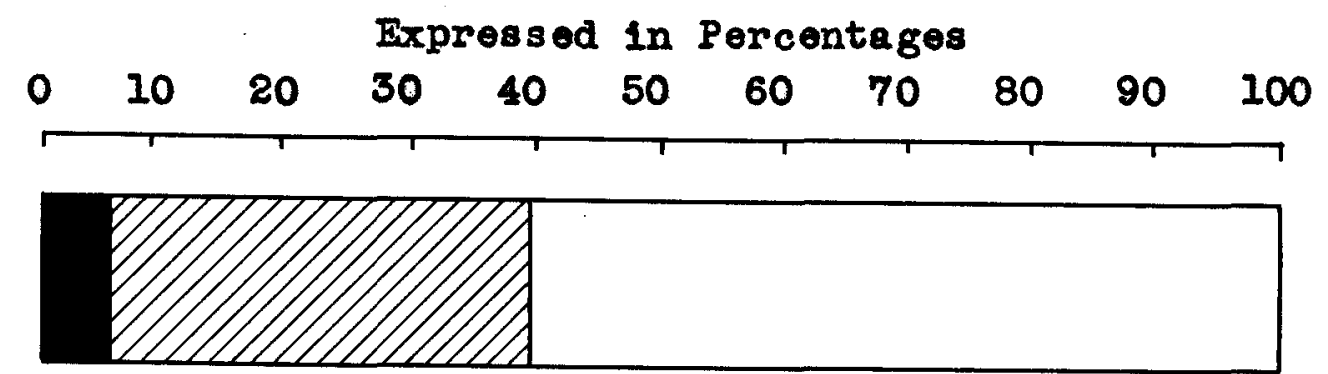

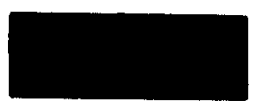

Often

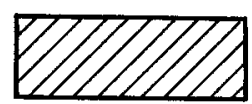

some

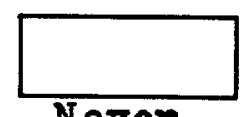

Nover

Figure 2.-Extent of use of phonograph records by Louis ville white fourth, fifth, and s ixth grade terchers. 
victrolas these figures would seem to indicate that this aid is not being used as extensively as possible.

Trips to parks were taken sometimes by 30 percent of the teachers, 70 percent never making such excursions. One percent of the teachers took their classes to Industrial plants often, 17 percent sometimes and 82 percent never took them. The remaining type of trip examined In the survey rated about the same results - 14 percent sometimes took classes or groups to observe physical features of the earth while 86 percent never did (se日 Figure 3).

\section{Expressed in Percentages}
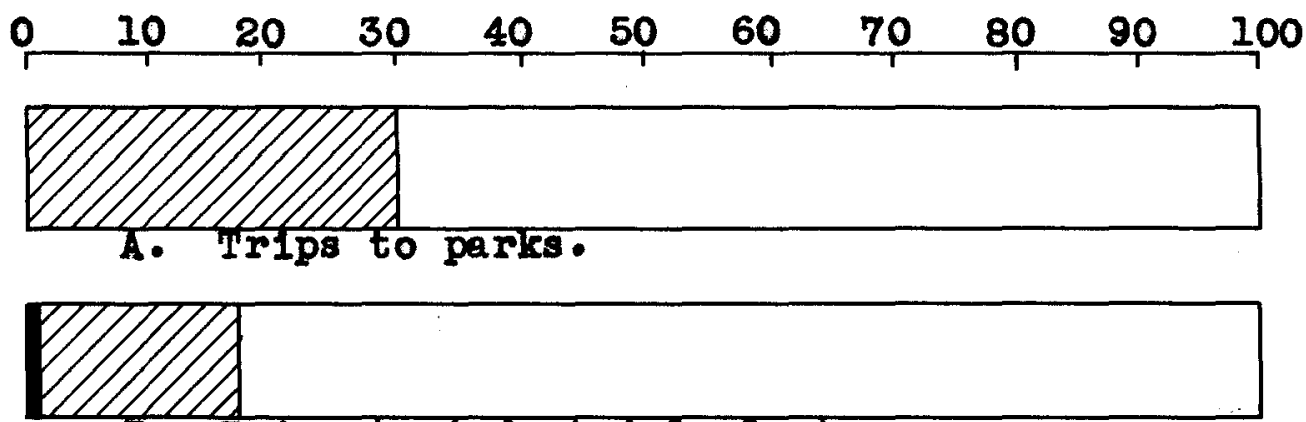

B. Trips to industrial plants.
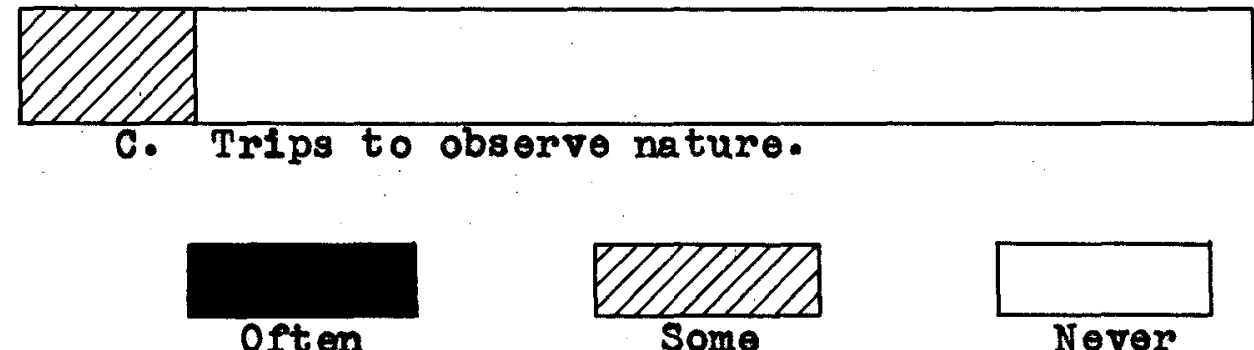

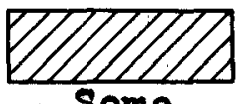

some

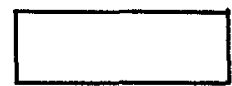

Never

Figure 3.-Extent of use of excursions by Louisville white fourth, fifth, and 1 ith grade teachers. 
Lantern slides, which ranked twelfth in extent of use, (see Table 1) were used often by 3 percent of the teachers, some by 21 percent and never by 86 percent. OnIy 2 percent of the teachers used stereoscopes often, 10 percent used them some and 88 percent never used them at all (see Figure 4). The Board of Education has 48 stereoscopes and 600 stereographs, but these figures would seom to indicate that only a few teachers used this aid.

Bxpressed in Percentages
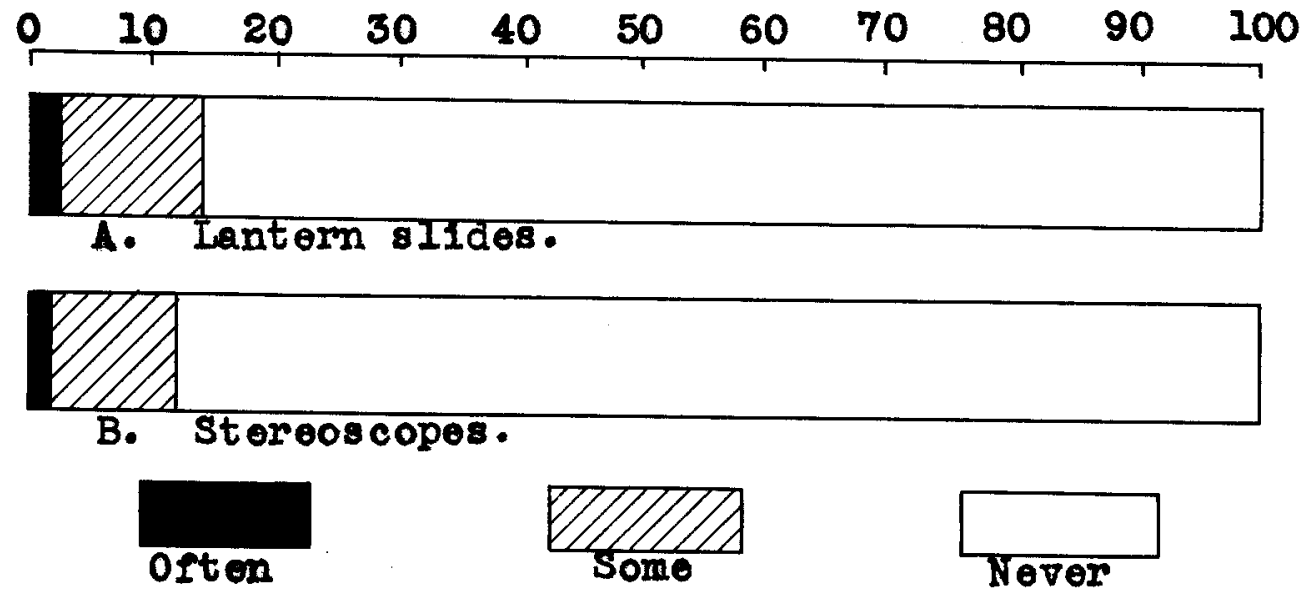

Figure 4.- Hatent of use of lantern slides and stereoscopes by Louisvilie white fourth, fifth, and sixth grade tea chers.

The flimstrip, another mechanlcal aid, seomed to fare no better as 11 percent claimed to have used it sometimes while 89 percent admitted never using it (see 
Figure 5). Upon checking the records of Mr. R. E. Daugherty, It was learned that the two f1lmstrips owned by the Board of Education were not used by any school during 1940-1941. The fact that quite a few teachers know nothing of this aid (ser Table III) no doubt accounts for 1ts disuse.

Expressed In Percentages

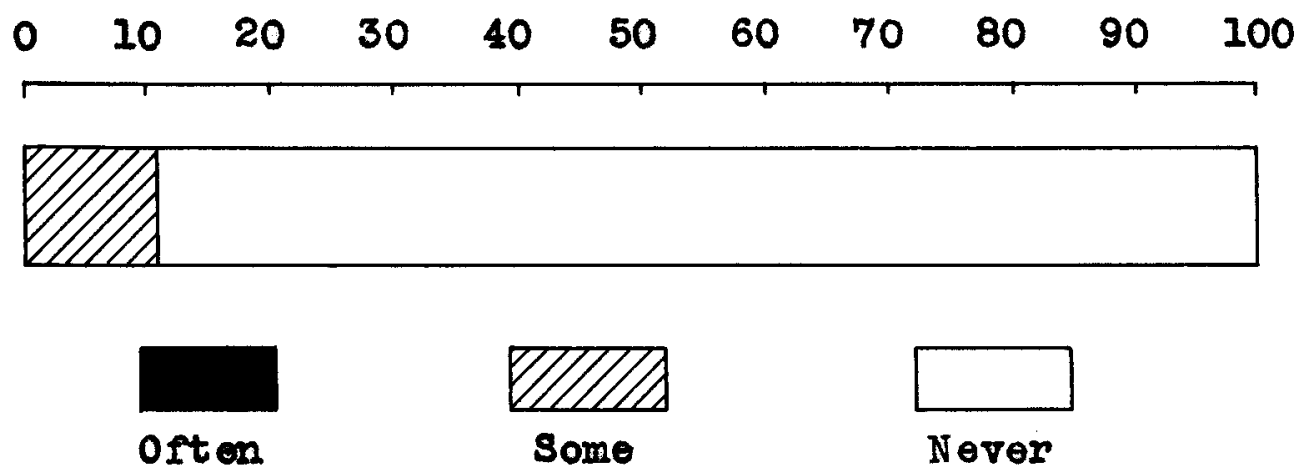

Figure 5.-Extent of use of filmstrips by Louisville white fourth, fifth, and sixth grade teachers.

\section{Microscope slides were also very sparingly}

used - 6 percent sometimes used them but 94 percent never did.

The opaque projector, which is also property of the Board of Education, was not used by any teacher during 1940-1941. The investigator borrowed it once this jear but found it so out-dated it was of no value in her teaching. 
TABLE III

AIDS WITH WHICH A NUMBER OF LOUISVILLE

WHITE FOURTH, FIFPH, AND SIXYH

GRADE TEACHERS ARE UNFAYILIAR

\begin{tabular}{|c|c|c|}
\hline Alds & $\frac{\text { Teachers Unfamiliar }}{\text { Actual Number }}$ & $\frac{\text { with Ald }}{\text { Percent }}$ \\
\hline Opaque Projector & 86 & 43 \\
\hline F1lmstrips & 34 & 17 \\
\hline Stereos copes & 26 & 13 \\
\hline Iantern slides & 16 & 8 \\
\hline M1eroscope slides & 14 & 7 \\
\hline Mot1on P1etures & 10 & 5 \\
\hline Phonograph Records & 4 & 2 \\
\hline School Excuraions & 2 & 1 \\
\hline Radio & 2 & 1 \\
\hline
\end{tabular}


This may be one reason why it is not being utilized by the Louis ville teachers, though probebly the main reason is the fact that so many teachers know nothing of this ald (seo Table III).

\section{Reasons Ilsted by Teachers for Not} Using Audio-Visual Alds

According to the survey the following reasons were given by the teachers for not making more use of audio-visuel alds:

A. 58 percent claimed they are unable to operate the projectors.

B. 52 percent stated audio-visual aid materials (film, slides, filmstrips, records) are too expensive.

C. 40 percent claimed that they do not know where to locate material.

D. 28 percent said they wore unable to secure material at desired time.

E. 22 percent stated that they were unable to secure sultablo material for grade.

F. 20 percent claimed they were unable to secure projectors at desired time.

G. 4 percent stated the1r bulldings or rooms are not equipped for projection. 
Framining the foregolng flgures, it will be noted that most of these reasons listed are a matter of administration. Showing the teachers how to operate projectors, getting the projectors and material to the teachers at time desired, sending out bulletins, informing teachers where to locate materials, and equipping the schoola for projection are problems to be administered and directed by the School Board. Many citles have solved these problems by centralizing all the audio-visual alds in one department, supervised by a capable, qualified person to serve as director. The director is then responsiblo for the purchasing, distributing, instructing, supervising, and maintaing of all audio-visual aids.

In many cities the superintendent, supervisors, and/or principal took the initiative in developing an audio-visual ald program. By having demonstrations, discussions, committee meetings, interesting lectures or courses in this fleld, they were able to arouse much interest, enthusiasm, and skill on the part of the teachers in the use of these alds. In some cities, however, the teachors were able to encourage more extensive purchasing of audio-visual alds by demonstrating to their superiors the great value gained in their usage in classroom instruction. Here in our city the situation seems to be more like the 
latter. The foeling is more or less prevalent that when teachers are interested and ready for audio-visual a1ds they will demand them. The material is purchased and placed at the Board of Education where it can be obtained by any teacher upon request. No attempt, heretofore, had been ade to interest or even acquaint the teachers with this material. However, this year (1942) one of the supervisors had a demonstration of several educational films. It 18 hoped that this will be the beginning of an audiovisuel ald progrem here in the Louis ville schools. The roason which ranks socond in importance by the Louis ville teachers was that of the problem of expense. Purchasing or renting audio-visual a1ds is very often too expensive for an individual teacher or groups of teachers. Here again many cities have found that the purchasing of as many audio-visual aids as possible by the school board, to be ut1lized by the whole school system, is more economical and officlent than having each indiridual sohool or groups of teachers buy their own material. However, in some instances where school boards have not been able to purchase mach of this material individual schools have bought their own audio-visual aids and have pooled this material among ach other. In this way mang teachers have been benefitted and while it is not the best plan it is at 
loast a beginning toward a regular audio-visual a1d department under a cepable and efficient director. Audio-V1sual Alds Unknom to Teachers Accoraing to Table III it will be noted that many Louis ville intermediate toachers are unfamiliar with some of the visuel aids examined in this survey, especialis those usually classified as mechanical aids. The flgures in Table III indicate that:

A. 43 percent of the teechors know nothing about the opaque projector.

B. 17 percent knew nothing about the filmstrips.

C. 13 percent were unfamiliar with stereos copes.

D. 8 percent were unfamiliar with lantern slides.

E. 7 percent knew nothing about microscope sl1des.

F. 5 percent knew nothing about the motion picture.

The figures further reveal that all the Iouisville white fourth, fifth, and sixth grade teachers were familiar with such alds as objects, spocimens, and models, graphs; charts and diagrams; maps and globes; and mounted pictures while 
only I percent admitted knowing nothing about the radio and school excursions and 2 percent had no knowledge of phonograph records.

Therefore Table III would seem to indicate that a number of Louis of the audio-visual alds, especially those requiring projection. As was stated previous is (pages 68 and 70) this 18 probably the chlef reason for their lack of use. To remedy this situation demonstrations of all types of audiovisual alds should be presented to the teachers in order to acquaint them with these materials.

\section{Audio-Visual Alds About Which Teachers} Desire More Information

Examining the figures in Table IV it appears quite significant that again the aids requiring mechanical equipment are the ones about which the Iouls vilie teachers are desirous of more information. According to the figures obtained from the questionnalre the following facts are reverled:

A. 26 percent of the teachers desired more information about the opaque projector.

B. 22 percent wished to know more about the motion picture and the f1lmstrip.

C. 14 percent desired more information about 
TABLE IV

AUDIO-VISUAL AIDS ABOUT WHICH

TEACHERS DESIRE MORE IMFORUATION

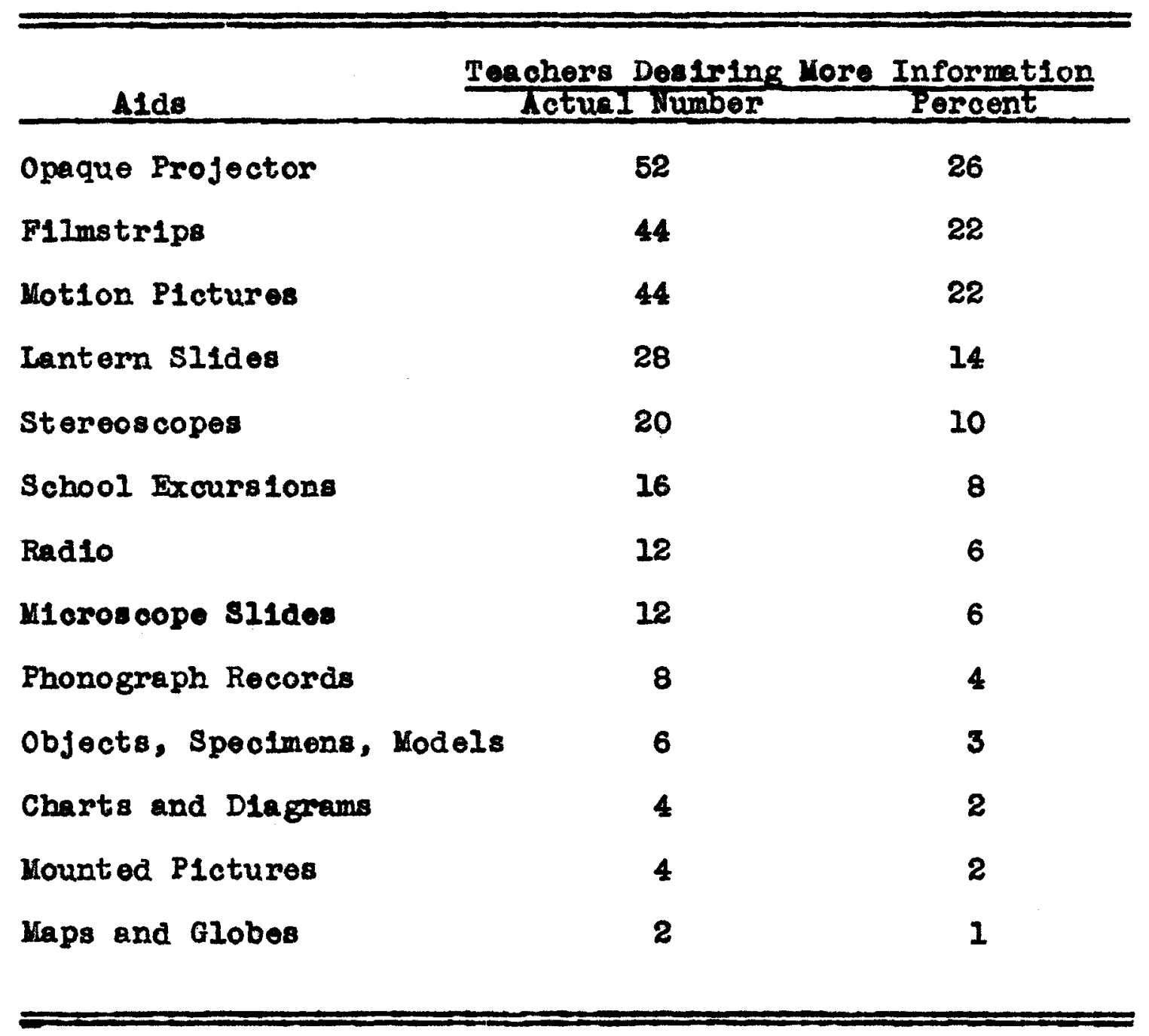


lantern slides.

D. 10 percent expressed a desire to learn more about stereoscopes.

The other audio-visual alds regarding which

1088 than 10 percent of the teachers requested information are included in Table IV.

Comparing Table IV with Table III it would appear that those alds with which the majority of teachers admitted being unfamiliar, are also those about which many teachers are desirous of more information. Therefore it should prove beneficial to provide demonstration lessons for these teachers, showing the different types of audio-visuel alds and their many uses. Bulletins containing reviows of the latest literature on this subject, or articles pertinent to this topic should bo sent to all toachers requesting them.

Aud10-V1sual A1ds in Which Teachers
Are Most Interested

Table $V$ reveals the following algniflcant data:

A. 56 percent of the teachers showed an interest in school excursions - 19 percent of them being interested in visiting civic institutions, 17 percent in visiting industrial plants, 10 percent in taking classes to parks, and 10 percent permitting classes 


\section{TABLE V}

AUDIO-VISUAL AIDS IN WHICH TEACHERS ARE MOST INTERESTED

\section{A1ds}

School Excursions

Motion Pictures

Radio

Maps and Globes

Mounted P1ctures

Objects, Specimens, Models

Phonograph Records

Charts and DIagrams

Graphe

Filmstrips

Iantorn SIidos

Stereoscopes

opeque Projector

M1croscope SIIdes
Teachers D1splaring Interest Lctual Number Porcent

96

48

82

41

76

38

66

33

60

30

52

26

42

21

38

19

32

16

28

14

20

10

14

7

12 
to observe nature.

B. 48 percent of the teachers were interested in motion pictures.

C. 41 percent were interested in the radio.

D. 38 percent were interested in maps and globes.

E. 33 percent were interested in mounted pictures.

F. 30 percent were interested in objects, specimens, and models.

G. 26 percent were interested in phonograph records.

For those alds which fall below 25 percent ser Table v.

Framining the above data it $\nabla 11$ be observed that over half of the terchers are interested in school excursions, a medium with which the teachers are very fomiliar (seo Table III). Since a large number of teachors are fomiliar and interested in "movies" and the radio as entertainment devices, mang of them are becoming interested in these media for educational purposes.

It w11l further be noted that all the other alds rating 30 percent or more of the interest of the Louisville teachers are those aids with which the teachers are quite 


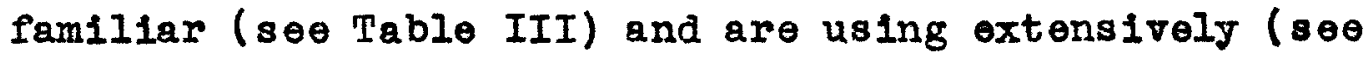
Table I).

$$
\text { Methods of Use* }
$$

This survey also included a study of the ways aud10-v1sual material best answered the neods of the Lou1svilie white fourth, fifth, and sixth grade teachers in their instmaction. Table VI roveals that of the 192 teachers (see Table I) using maps and globes, 61 percent used them to answer specific questions that were assigned; 54 percent to introduce a unit or subject; 52 percent to gain additional information; and 44 percent to stimulato discussion. Thus it would appear, from the above figures, that the majority of the 192 teachers using maps and globes are making good us of this a id in their teaching. Table VI contains the additional ways the teachers havo used maps and globes other than those mentioned above.

Next in use among the Louisville teachers were mount ed pletures with a following of 184. Of this number 82 percent provided plctures to introduce a unit or subject; 67 percent to stimulate discussion; 54 percent to develop a keenness of observation; 53 percent to increase voluntary reading; 49 percent to gain additional information; and 48 percent to 1llustrate facts already. known. literature in this field. 
TABIE VI

WAYS IN WHICH MAPS AND GLOBES BEST ANSWERED THE NEEDS OF ONE HUNDRED AND NINBIY-TWO IOUISVILLE WHITE, FOUPUH, FIFTH, AND SIXIH GRADE TEACHERS

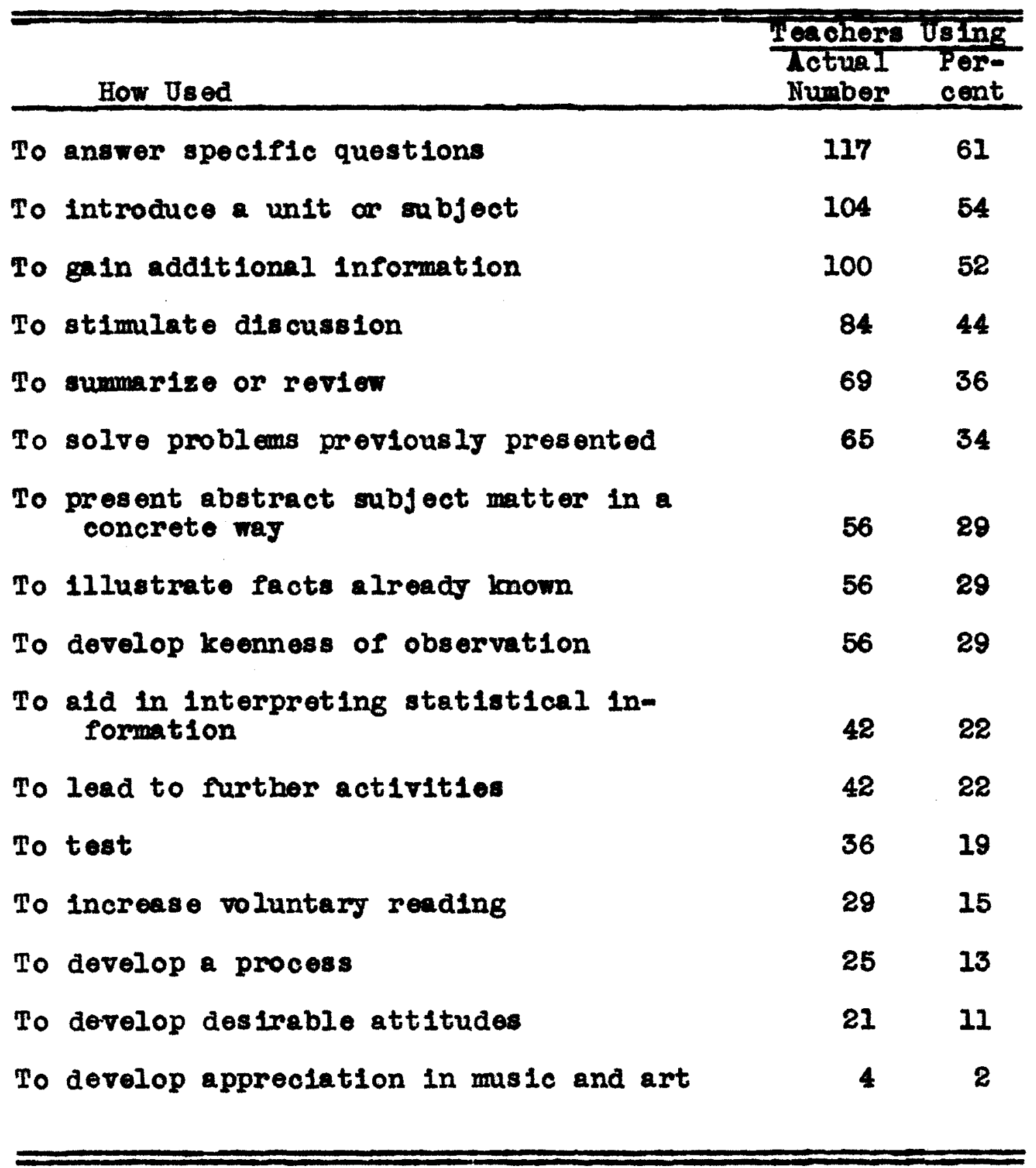


Judging from the above percentages, it would seom that these 184 Loulsville teachers are also making wise cholce in their use of plotures. Because the other methods were not used by a sufficiently large number to be significant they have not been listed here. The reader will find this information in Table VII.

According to Tablo VIII, charts and diagrams, which were used by 164 teachers, were presented by 63 percent to aid in interpreting statistical information; by 43 percent as a summary or revlew; by 42 percent to present abstract subject mattor in a concrete way; by 35 percont to stimlato discussion; and 32 porcent to illustrate facts already known. Whilo charts and diagrams are of great value in terching statistical information, they can be of mach assistance in stimulating discussion, illustratIng facts already known, galning additional information, and solving problems previously presented. According to the above figures it would soem that many of the Ioulsville teachers are using charts and diagrams for statistical purposes only and are overlooking some of thelr other values (seo Table VIII).

Objects, specimens, and models were used by 146 teachers. Seventy-nine percent of this number introduced a unit or subject with these media; 58 percent used them to 
TABLE VII

WAYS IN WHICH YOUNTED PICTURES BEST ANSWERED THE NEEDS OF ONE HUNDRED AND EIGHIY-FOUR LOUISVILLE WHITE FOURTH, FIFTH, AND SIXTH GRADE TEACHERS

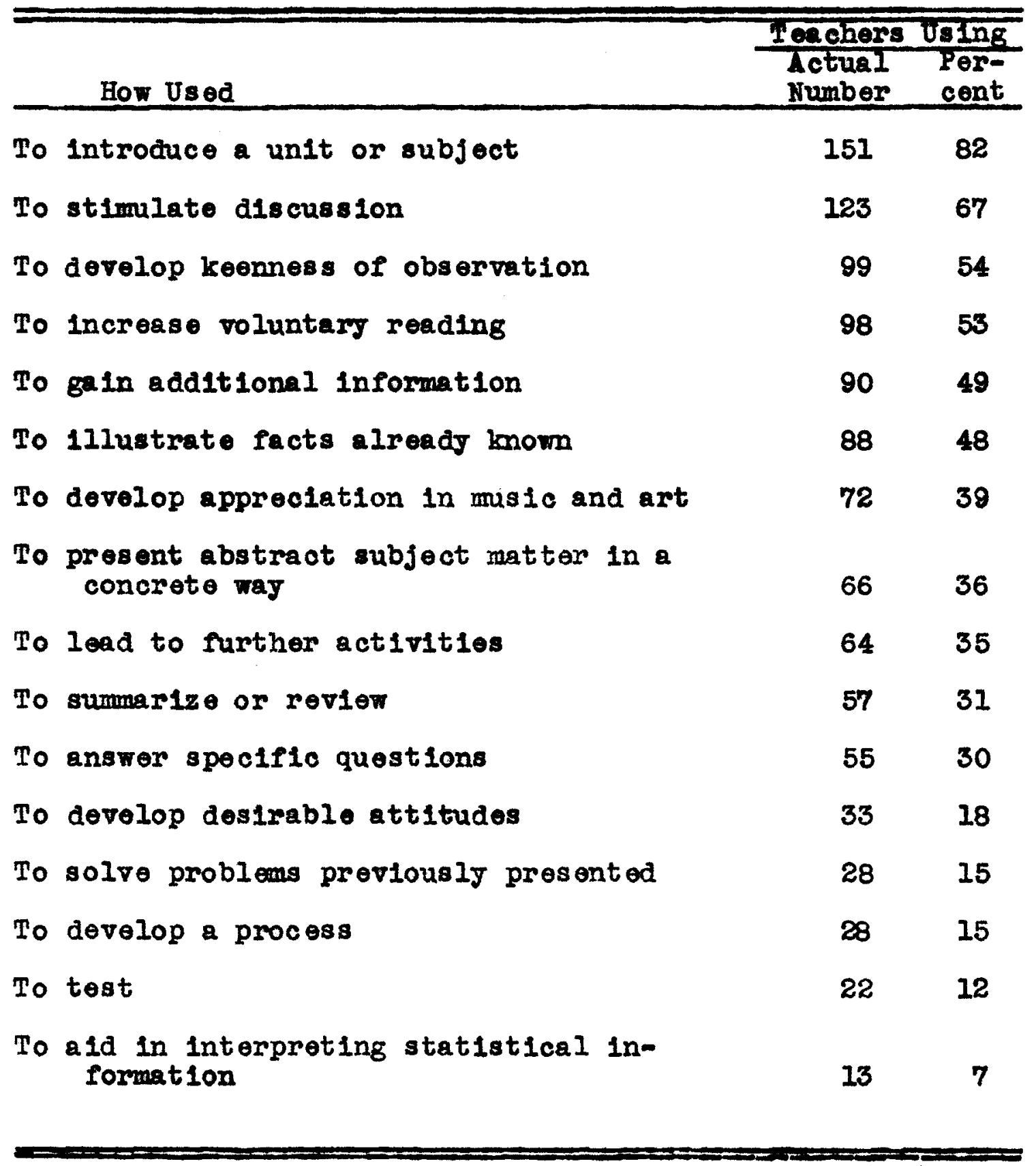




\section{TABLE VIII}

WAYS IN WHICH CHARTS AND DIAGRAMS BEST ANSWERED THE NEEDS OF ONE HUNDRED AND SIXIY-FOUR IOUISVILLE WHITE FOURTH, FIFTH, AND SDXTH GRADE TEACHERS

\begin{tabular}{|c|c|c|}
\hline How Used & $\begin{array}{c}\text { Teechors } \\
\text { Actual } \\
\text { Number }\end{array}$ & $\begin{array}{l}\text { Using } \\
\text { Per: } \\
\text { cent }\end{array}$ \\
\hline $\begin{array}{l}\text { To aid in interpreting statistical in- } \\
\text { formation }\end{array}$ & 103 & 63 \\
\hline To summarize or review & 71 & 43 \\
\hline $\begin{array}{l}\text { To present abstract subject matter in a } \\
\text { concrete way }\end{array}$ & 69 & 42 \\
\hline To stimalate discussion & 57 & 35 \\
\hline To lllustrate facts already known & 52 & 32 \\
\hline To in additional information & 48 & 29 \\
\hline To answer speciflc questions & 43 & 26 \\
\hline To solve problems previously presented & 43 & 26 \\
\hline To introduce a unit or subject & 39 & 24 \\
\hline To dovelop keonness of observation & 33 & 20 \\
\hline To test & 30 & 18 \\
\hline To develop a prooess & 28 & 17 \\
\hline To load to further act1vitios & 25 & 15 \\
\hline To increase voluntary reading & 20 & 12 \\
\hline To develop desirable attitudes & 16 & 10 \\
\hline To develop appreciation in masic and art & 2 & 1 \\
\hline
\end{tabular}


present abstract subject matter in a concrete way; 58 percent stimulated discussions by means of them; 41 percent used them to ga in additional information; and 41 percent presented them to develop keenness of observation (see Table IX). These percentages probably indicate that these 146 Louisville teachers are using objects, specimens, and models to good advantage in their teaching. According to the survey it was found that 144 Louls ville teachers use graphs in their teaching, 83 percent furnishing them to ald in interpreting statistical data, which is no doubt their greatest value (see Chapter III). Graphs wero also used by 44 percent as a summary while 41 percent used them to 1llustrate facts already known (seo $\mathrm{Table} X)$.

The results of the questionnaire show that 140 Louls ville white fourth, fifth, and sixth grade torchers are making use of the radio in their terching, 79 percent of them employing this ald to derelop approciation in mus1c. Forty percent of the teachers used the rad10 to gain additional information; 30 percent reported that the radio alded them in stimulating discussions; whilo 26 percent stated that the radio was an aid in developing desirable attitudes. These figures would seem to indicate that the majority of the 140 Loulaville teachers utilizing the 
TABLE IX

WAYS IN WHICH OBJECTS, SPECIMENS, AND YODELS BEST ANSWERED THE NEEDS OF ONE HUNDRED AND FORTY-SIX

IOUISVILLE WHITE FOURTH, FIFTH,

AND SIXTH GRADE TEACHERS

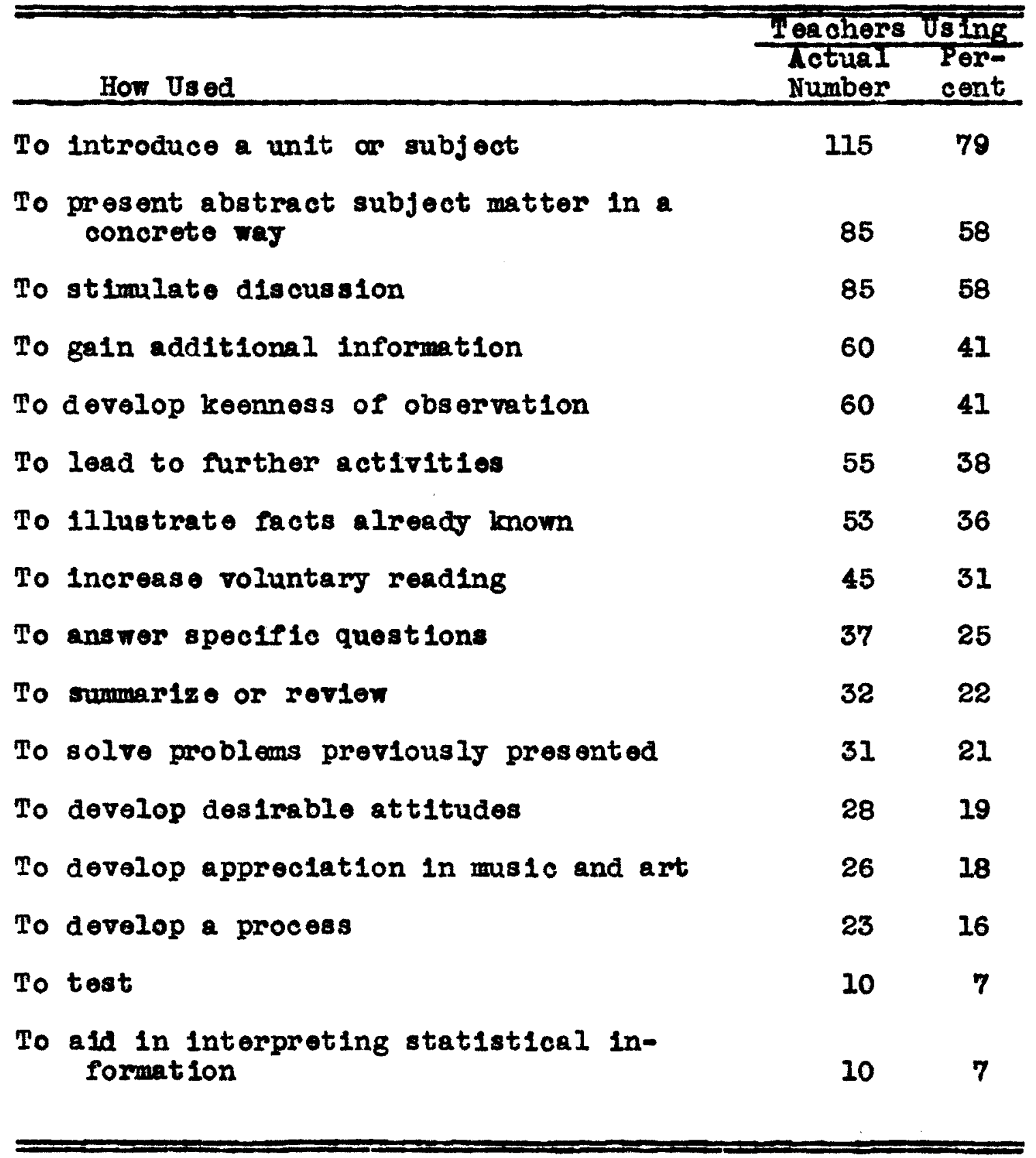


TABLE $\mathrm{X}$

WAYS IN WHICH GRAPHS BEST ANSWERED THE NEEDS OF

ONE HUNDRED AND FORIY-FOUR IOUISVILLE WHITE FOURTH, FIFTH, AND SIXTH GRADE TEACHERS

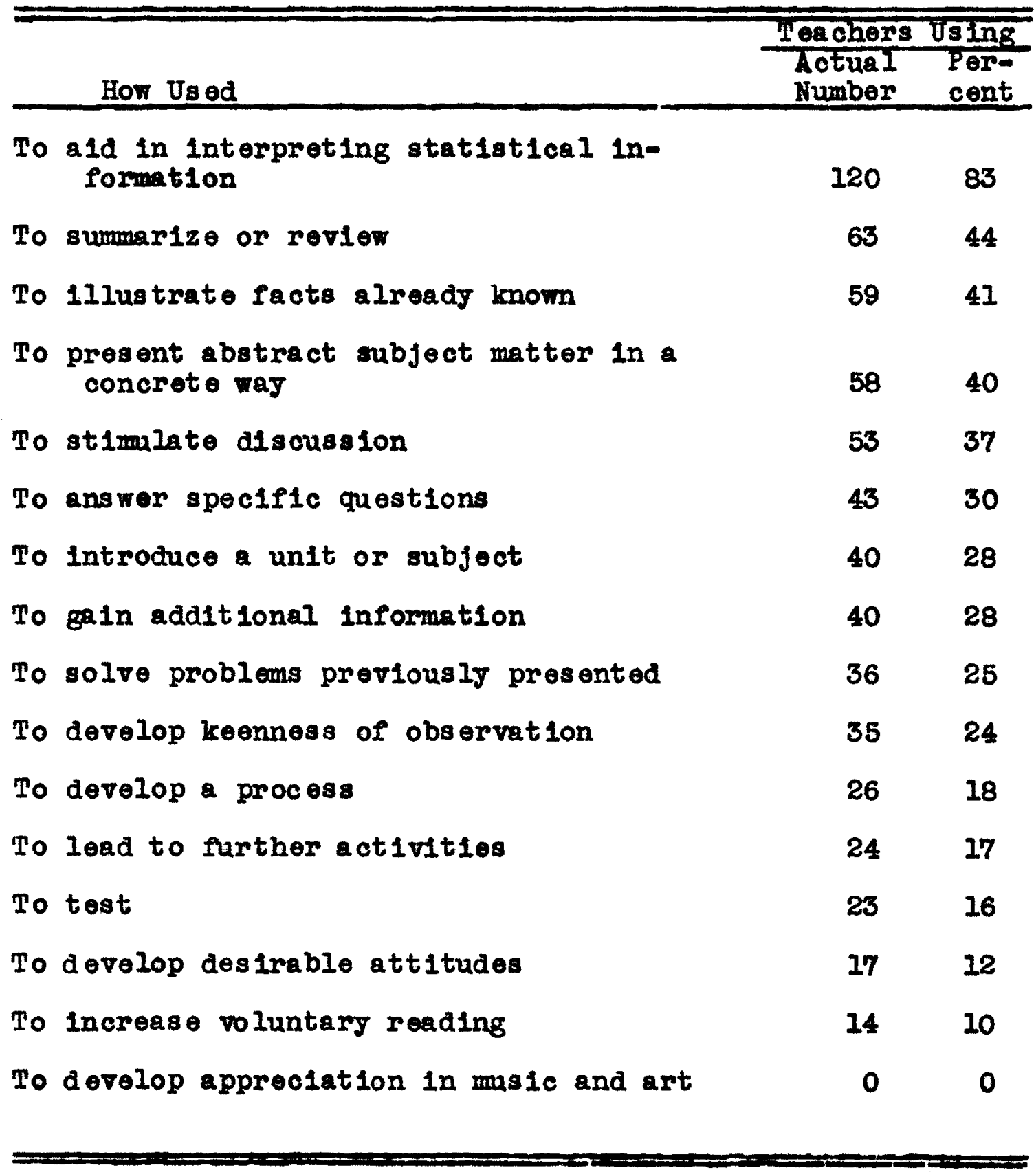


radio are using it for musical purposes, but are ignoring meny of its other values (ser Table XI).

Although only one-half of the Louls ville teachers took thelr children on excursions (see Table I) many of them - 73 percent - reported that they found excursions of mach value in helping the children gain additional information concerning a topic or subject they were studying. Sixty-nine percent of them stated that excursions stimulated discussions; 63 percent used them to develop keonness of observation; wh1le 60 percent reported that excursions led to further activitios. Excursions were also used by 56 percent to increase voluntary reading; by 53 percent to introduce a subject or unit; and by 51 percent to develop desirable attitudes. Thus these flgures probably indicate that even though only one-half of the Iouisville teachers are taking their children on trips, these 100 teachers are finding excursions of unlimited value in a variety of ways (seo Table XII).

Table XIII reveals that the motion picture, which was utilized by 96 teachers (see Table I), was used by 55 percent of them to gain additional information; 40 percent to stimulate discussion; 39 percent to develop keenness of observation; 33 percent to develop desirable attitudes; 33 percent to increase voluntary reading; 33 percent to lead 
TABLE XI

WAYS IN WHICH RADIO BEST ANSWERED THE NEEDS OF ONE HUNDRED AND FORTY LOUISVILLE WHITE FOURTH, FIFTH, AND SIXYH GRADE TEACHERS

\begin{tabular}{|c|c|c|}
\hline How Used & $\begin{array}{l}\text { Teachers } \\
\text { Nctual } \\
\text { Number }\end{array}$ & $\begin{array}{l}\text { Using } \\
\text { Perr } \\
\text { cent }\end{array}$ \\
\hline To develop appreciation in masic and art & 111 & 79 \\
\hline To gein additional information & 56 & 40 \\
\hline To stimlato discussion & 42 & 30 \\
\hline To develop desirable attitudes & 36 & 26 \\
\hline To load to furthor activitios & 34 & 24 \\
\hline To devel op keenness of observation & 21 & 15 \\
\hline To increase voluntary reading & 21 & 15 \\
\hline To introduce a unit or subject & 17 & 12 \\
\hline To summarize or review & 15 & 11 \\
\hline To 1llustrate facts already known & 15 & 11 \\
\hline $\begin{array}{l}\text { To present abstraot subject matter in a } \\
\text { concrete way }\end{array}$ & 13 & 9 \\
\hline To answer spocific questions & 8 & 6 \\
\hline To develop a process & 7 & 5 \\
\hline To test & 6 & 4 \\
\hline To solve problems previously presented & 6 & 4 \\
\hline $\begin{array}{l}\text { To aid in interpreting statistical in- } \\
\text { formation }\end{array}$ & 3 & 2 \\
\hline
\end{tabular}


TABLE XII

WAYS IN WHICH EXCURSIONS BEST ANSWERED THE NEEDS OF ONE HUNDRED LOUISVILLE WHITE FOURIH,

FIFTH, AND SIXTH GRADE TEACHERS

\begin{tabular}{|c|c|c|}
\hline How Used & $\begin{array}{l}\text { Teqohers } \\
\text { ActuaI } \\
\text { Number }\end{array}$ & $\begin{array}{l}\text { Jolng } \\
\text { Pera } \\
\text { cent }\end{array}$ \\
\hline To gain additional information & 73 & 73 \\
\hline To stimilato discussion & 69 & 69 \\
\hline To develop keenness of observation & 63 & 63 \\
\hline To lead to further activities & 60 & 60 \\
\hline To increase voluntary reading & 56 & 56 \\
\hline To introduce a unit or subject & 53 & 53 \\
\hline To develop desirable attitudes & 51 & 51 \\
\hline To develop apprectation in music and art & 40 & 40 \\
\hline To answer specific questions & 38 & 38 \\
\hline To summarize or review & 31 & 31 \\
\hline $\begin{array}{l}\text { To present abstract subject matter in a } \\
\text { concrete way }\end{array}$ & 28 & 28 \\
\hline To solve problems previously presented & 28 & 28 \\
\hline To 1llustrate facts already known & 20 & 20 \\
\hline To develop a process & 11 & 11 \\
\hline $\begin{array}{l}\text { To ald in interpreting statistical in- } \\
\text { formation }\end{array}$ & 5 & 5 \\
\hline To test & 2 & 2 \\
\hline
\end{tabular}


to further activities; 32 percent to introduce a unit or subject; 31 percent as a summary or review; and 30 percent to 1llustrate facts already known. Judging from the above figures (see Table XIII) it would seem that the motion picture is being utilized in a varlety of ways by at least one-third of the teechers using this medsum, but that most of them are not familiar with its many advantages. This may be die to the fact that many of these 96 teachors are not securing and ut1lizing flims of thelr own cho1ce in connection with their teaching (se日 page 64), but are depending on outside agencies to furnish them occesionally with films on such topics as health and safety. According to Table I, 80 teachers reported that they used phonograph records, and out of th1s number 96 percent used them to develop appreciation in music, which 1s probably their greatest value (see Table XIV).

Table XV shows that of the 28 Louls ville teachors using lantern slides over one-half employed them to aid their classes in gaining additional information, and to stimulate discussion; about one-half used them as a sumary or reviev, to develop keenness of observation, and to 1llustrate facts already known. Seo Table XV for further uses. These figures apparently indicate that although lantern slides are boing used by only 28 teachers, these few 


\section{TABLE XIII}

WAYS IN WHICH MOTION PICTURES BEST ANSWERED THE NEEDS OF NINETY-SIX IOUISVILLE WHITE FOURTH, FIFTH, AND SIXTH GRADE TEACHERS

\begin{tabular}{|c|c|c|}
\hline How Used & $\begin{array}{l}\text { Teacher: } \\
\text { Nctual } \\
\text { Number }\end{array}$ & $\begin{array}{l}\text { ofing } \\
\text { Per } \\
\text { cent }\end{array}$ \\
\hline To gain additional information & 53 & 55 \\
\hline To stimulate discussion & 38 & 40 \\
\hline To develop keenness of observation & 37 & 39 \\
\hline To develop desirable attitudes & 32 & 33 \\
\hline To increase voluntary reading & 32 & 33 \\
\hline To lead to further activiti es & 32 & 33 \\
\hline To introduce a unit or subject & 31 & 32 \\
\hline To summarize or revier & 30 & 31 \\
\hline To 1llustrate facts a.lroad known & 29 & 30 \\
\hline To develop appreciation in masic and art & 25 & 26 \\
\hline $\begin{array}{l}\text { To present abstract subject matter in a } \\
\text { concrete way }\end{array}$ & 20 & 21 \\
\hline To answer s pecific questions & 14 & 15 \\
\hline To solve problems previously pesented & 12 & 13 \\
\hline To develop a process & 7 & 7 \\
\hline $\begin{array}{l}\text { To aid in interpreting statistical in- } \\
\text { formation }\end{array}$ & 5 & 5 \\
\hline To test & 3 & 3 \\
\hline
\end{tabular}


TABLE XIV

WAYS IN WHICH PHONOGRAPH RECORDS BEST ANSWERED THE NEEDS OF EIGHYY IOUISVIILE WHIIE FOURTH, FIFTH, AND SIXTH GRADE TEACHERS

\begin{tabular}{|c|c|c|}
\hline Hon Used & $\begin{array}{l}\text { Teachers } \\
\text { Actual } \\
\text { Number }\end{array}$ & $\begin{array}{l}\text { Jeng } \\
\text { Per- } \\
\text { cent }\end{array}$ \\
\hline To develop appreciation in music and art & 77 & 96 \\
\hline To load to further activitios & 16 & 20 \\
\hline To develop desirable attitudes & 16 & 20 \\
\hline To develop keenness of observation & 12 & 15 \\
\hline To gain additional information & 10 & 13 \\
\hline To stimalate discussion & 10 & 13 \\
\hline To introduce a unit or subject & 10 & 13 \\
\hline To summarize or review & 8 & 10 \\
\hline To incresse voluntary roeding & 6 & 7 \\
\hline To tost & 5 & 6 \\
\hline To 1llustrate facts already known & 5 & 6 \\
\hline $\begin{array}{l}\text { To present abstract subject mattor in a } \\
\text { concrete way }\end{array}$ & 4 & 5 \\
\hline To answer specific questions & 2 & 3 \\
\hline To solve problems previously presented & 1 & 1 \\
\hline To develop a process & 1 & 1 \\
\hline $\begin{array}{l}\text { To aid in interpreting statistical in- } \\
\text { formation }\end{array}$ & 0 & 0 \\
\hline
\end{tabular}


TABLE XV

WAYS IN WHICH LANTERN SLIDES BEST ANSWERED THE NETES OF TWEWTY-EIGEII LOUISVILLE WHITE FOURTH, FIFTH, AND SIXTH GRADE TEACHERS

\begin{tabular}{|c|c|c|}
\hline How Used & $\begin{array}{l}\text { Teachers } \\
\text { Actual } \\
\text { Number }\end{array}$ & $\begin{array}{l}\text { Using } \\
\text { Per- } \\
\text { cont }\end{array}$ \\
\hline To gain additional information & 16 & 56 \\
\hline To stimlate discussion & 15 & 54 \\
\hline To summarize or revien & 14 & 50 \\
\hline To develop keenness of observation & 13 & 46 \\
\hline To 1llustrate facts alroady known & 12 & 43 \\
\hline To introduce a unit or subject & 10 & 36 \\
\hline To answer specific questions & 10 & 36 \\
\hline To lead to further activities & 10 & 36 \\
\hline $\begin{array}{l}\text { To present abstract subject matter in a } \\
\text { concrete way }\end{array}$ & 8 & 29 \\
\hline To develop desirable attitudes & 8 & 29 \\
\hline To increase voluntary reading & 8 & 29 \\
\hline To solve problems previousiy presented & 6 & 22 \\
\hline To develop a process & 5 & 18 \\
\hline To tost & 4 & 14 \\
\hline To develop appreciation in maic and art & 3 & 11 \\
\hline $\begin{array}{l}\text { To aid in interpreting statistical in- } \\
\text { formation }\end{array}$ & 1 & 4 \\
\hline
\end{tabular}


teachers are utilizing them to good advantage.

Stereoscopes were used by 24 Loulsville teachers, fourteen of these stating that stereoscopes were valuable in developing keenness of observation, while one-half of them provided stereoscopes to assist their children in gaining additional information on some tople studied. Stereoscopes were used to stimulate discussion by nine of the teachers and to increase voluntary reading by eight of them. Thus, judging from the above figures, it would seem that the small group of Loufsillie teachers utilizing stereoscopes are employing them in their teaching quite effectively. For further uses se日 Table XVI.

Twenty-two Loulsville teachers utilized the fllmstrip, one-half of them employing this aid to gain additional information. Ton of the teachers used the filmstrip to develop desirable attitudes while nine reported this ald valuable in the following ways - to introduce a unit or subject, to stimulate discussion, to increase voluntary reading, and to lead to further activities. For further usos seo Table XVII. These figures probably indicate that the filmstrip is being used effectively by a small group of Louis ville teachers.

of the 12 Louisville teachers using microscope 


\section{TABLE XVI}

WAYS IN WHICH STEREOSCOPES BEST ANSWERED THE NEEDS OF TWENTY-FOUR LOUISVILLE WHITE FOURTH, FIFTH, AND SIXTH GRADE TEACHERS

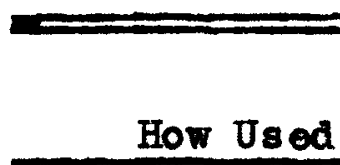

To develop keenness of observation

To gain additional information

To stimalate discussion

To increase voluntary reading

To lead to rurther activities

To illustrate facts alroady known

To introduce a unit or subject

To develop desirable attitudes

To sumarize or roview

To present abstract subject matter in a concrete way

To test

To develop appreciation in musio and art

To solve problems previously presented

To develop a process

To answer specific questions

To a1d in interpreting statistical information
Terchers Using Actual Pore Number cont

14

58

12

50

9

38

$8 \quad 34$

$7 \quad 29$

625

$5 \quad 21$

$5 \quad 21$

$3 \quad 13$

3

13

$3 \quad 13$

$3 \quad 13$

28

28

14

1 4 
TABLE XVII

WAYS IN WHICH FIIMSTRIPS BEST ANSWERED THE NEEDS

OF TWETTY-TWO LOUISVIILE WHITE FOURTH,

FIFTH, AND SIXTH GRADE TEACHERS

\begin{tabular}{|c|c|c|}
\hline How Used & $\begin{array}{l}\text { Teachers } \\
\text { Actual } \\
\text { Number }\end{array}$ & $\begin{array}{l}\text { Using } \\
\text { cers } \\
\text { cent }\end{array}$ \\
\hline To gain additional information & 11 & 50 \\
\hline To develop keenness of observation & 10 & 45 \\
\hline To introduce a unit or subject & 9 & 41 \\
\hline To stimulate discussion & 9 & 41 \\
\hline To increese voluntary reading & 8 & 41 \\
\hline To lead to further activities & 9 & 41 \\
\hline To 1llustrate facts already known & 8 & 36 \\
\hline $\begin{array}{l}\text { To present abstract subject matter in a } \\
\text { concrete way }\end{array}$ & 7 & 32 \\
\hline To develop desirable attitudes & 7 & 32 \\
\hline To answer spocific questions & 6 & 27 \\
\hline To sumarize or revien & 5 & 23 \\
\hline To develop a process & 5 & 23 \\
\hline To solve problens previously presented & 4 & 18 \\
\hline To develop appreciation in music and art & 4 & 18 \\
\hline To test & 1 & 5 \\
\hline $\begin{array}{l}\text { To a id in interpreting statistical in- } \\
\text { formation }\end{array}$ & 1 & 5 \\
\hline
\end{tabular}


slides in their teaching, one-half of them found these slides useful in presenting abstract subject matter in a concrete way, and in developing keenness of observation. Five of the teachers used them to stimalate discussion and to lead to further activities, while onethird of them found thom helpful in developing desirablo attitudes and in increasing voluntary reading. These figures seem to indicate that microscope slides are being used advantageously by a very small group of Loulgville teachers (see Table XVIII).

Value of Audio-Visual A1ds When Supplemented With Books in Instruction

The investigator wished to determine how valuable the Loulsvilie teachers considered audio-visual alds in Instmaction when supplemented with books; therefore, this problem was included in the questionna1ro. A list of fifteen main advantages of audio-visual alds was submitted. These fifteen advantages were selected after a careful study of many important scientific experiments and the writings of the most prominent audio-visual ald authorities. The teachers were to express their opinions by elther agreeing or disagreoing with each statement. The results are shown in the following table. From this table 1t w1ll be noted that the majority of the 200 Loulsville 
TABLE XVIII

WAYS IN WHICH MICROSCOPE SLIDES BEST ANSWERED

THE NEEDS OF TWELVE IOUISVILIE WHITE FOURTH, FIFTH, AND SIXTH GRADE TEACHERS

\begin{tabular}{ll}
\hline Tow Used & $\begin{array}{r}\text { Toars Using } \\
\text { Actual Por- } \\
\text { Number cent }\end{array}$ \\
\hline
\end{tabular}

To present abstract subject matter in a concrete way

To derelop keenness of observation

To stimilate discussion

To lead to further activities

To develop desirable attitudes

To increase voluntary reading

To sumnarize or review $3 \quad 25$

To gain additional information $3 \quad 25$

To answer specific questions

To 1llustrate facts already known

To introduce a unit or subject

To develop a process

To test

18

To develop appreciation in music and art

To solve problems previously presented

0

0

To aid in interpreting statistical information

0 
teachers questioned agreed with most of the statements that audio-visual aids are a valuable media when supplemented with books in instruction. However, it will be noted that many teachers expressed different viewpoints on three of the above statements as listed in Table XIX; 53 percent agreed that audio-visual aids are valuable in lessening problems of discipline, 26 percent disagreed and 21 percent expressed no opinion. Sixty-two percent agreod that visual aids provide individual instruction for pupils, 18 percent disagreed, and 20 percent expressed no opinion. The third statement in which there was a difference of opinion was that in regard to the effects of audio-visual aids on economy of time in learning. Sixtyfour pereent agreed, 17 percent disagreed, and 19 percent expressed no viewpoint. However, it is quite significant to note that many sclentific experiments have proved the affirmat1ve of all three of these statements (see Chapter IV).

Suggestions and Recommendations Made by Louisville Teachers for Establishing an Audio-V1sual Aid Program

The questionnalre also allowed the teachers to offer suggestions and recommendations for establishing an audio-visual ald program in the Louisville public schools. The following suggestions were advanced by many teachers: 1. The Board of Education should provide more 
TABLE XIX

WAYS IN WHICH AUDIO-VISUAL AIDS ARE VALUABLE IN INSTRUCTION WHEN SUPPLEMENTED WITH BOOKS

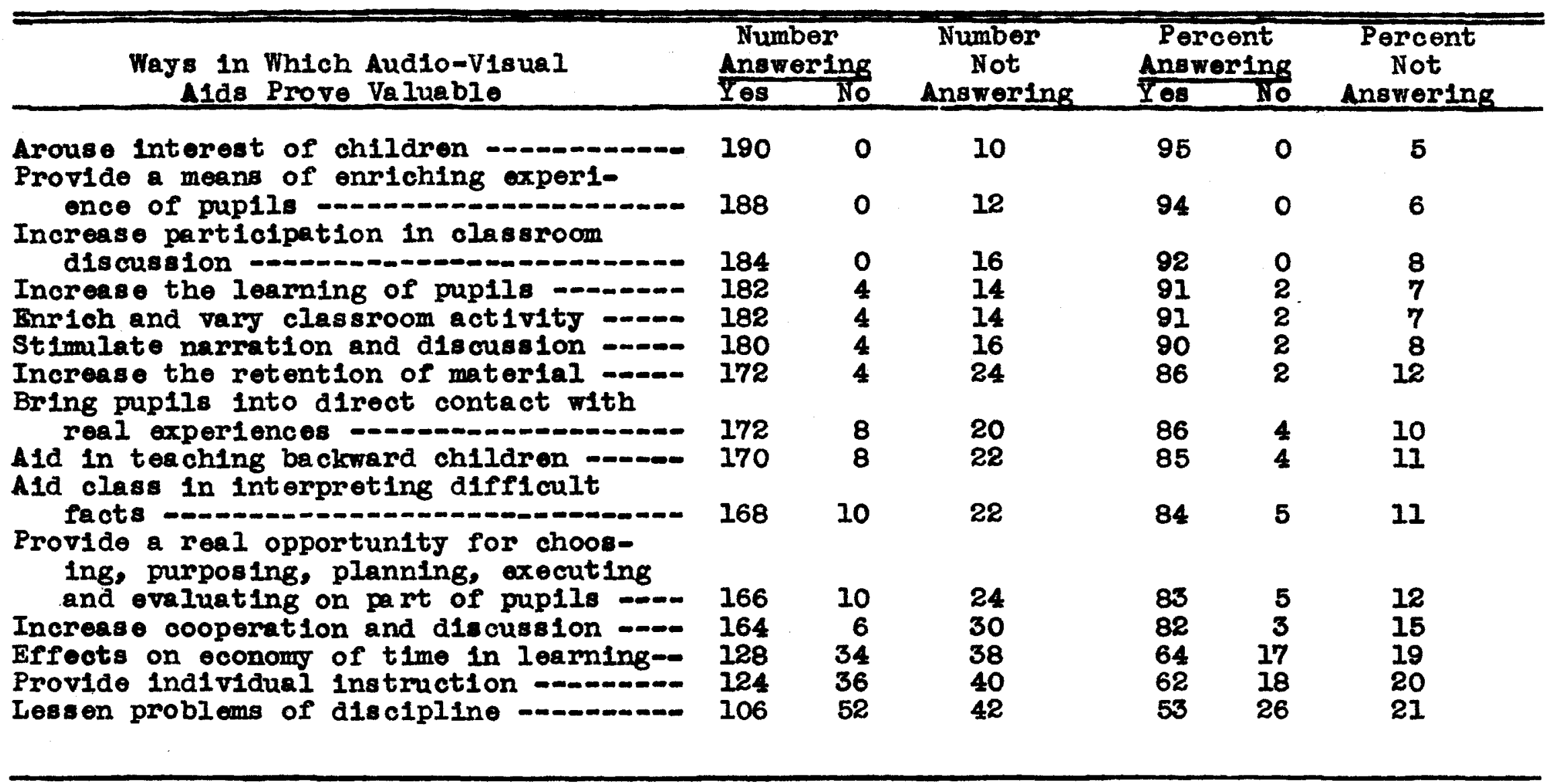


audio-visual aid material for instruction.

2. Some plan similar to our present traveling library should be established to distribute audiovisual ald material throughout the school system. 3. Bulletins should be provided to inform teachers where audio-risual alds can be obtained.

4. Teachers should be instructed how to operate projectors.

To summarize the principal findings of this survey as discussed in this chapter, it will be noted that:

1. The majority of the 200 Louls ville teachers questioned are utilizing more extensively the nonmechanical aids than those which require machines for projection.

2. Many of these Loulsvilie teachers are not utilizing mechanical alds because of their inability to operate projectors and because these audio-visual alds are too expensive.

3. Many of these Loulsville teachers admit being totaliy unfamilier with some of these alds, especially the mechanical ones.

4. The majority of the 200 Louis vilie teachers replying to the questionnaire are interested in the alds with wich they are most familiar - the motion 
picture and radio probably attaining a high percentage because of their entertainment value.

5. Quite a number of teachers desire more information about many of these alds, especially those requiring projection.

6. The majority of these 200 Louls ville teachers are utilizing these alds to good advantage in their Instmaction, with the probable exception of charts and diagrams, the radio, and the motion picture.

7. The majority of these Louisville teachers consider audo-visual alds valuable media when supplemented with books in instruction.

8. Manj Lou1sville teachers desire more aud10visual alds to be provided for their instruction. 
CONCLUSIONS AND RECOMMENDATIONS 
CHAPTER VI

CONCLUSIONS AND RECOMMENDATIONS

As was shown in Chapter $V$, the majority of Louisv1110 white teachers in the fourth, fifth, and sixth grades are using maps and globes, mounted pictures, and charts and diagrams more than any other a1d. Inasmuch as the Board of Education has provided the Loulstille schools with maps and globes for many years, the majority of the white fourth, fifth, and s1xth grade teachers are, of course, familiar with these alds and use them extensively. Since mounted plctures and charts and diagrams are easily obtainable and are comparatively inexpensive many Loulsville teachers are 21 so very familiar with these alds and are utilizing them extensively.

However, it is also apparent that many Loulsvilie teachers know very little about some of the audiovioual ald axamined in this survey. According to the results obtained in this survey, a groat number of Loulsville toachors are quite unfamiliar with such alds as the flimstrip, opaque projector, stereoscopes and motion pictures, and are therefore using these alds very meagerly (see Table I, pege 60 and Table III, page 69).

Many Loulsvilie teachors evidently do not know 
that the Louisvilie Board of Education has two filmstrip projectors with twenty-six films relating to the United States and its possessions, has three Ampro sound motion plcture projectors, one opaque projector, and forty-elght stereoscopes with a complete set of stereographs dealing with practically every subject. All this material can bo borrowed from the Board of Education by any teacher at any time. These supplies should be in constant demand and use and yet, according to the results of the survey, it can be seen that only twenty-two teachers out of the 200 questioned used the filmstrip, ninety-six used the motion picture, none the opaque projector (seo chapter V, page 68), and twentyfour the stereoscopes. Therefore, it would seem most pract1cable to inform the teachers of all the audio-risual alds which the Bosid of Education has on hand and which can be borrowed by the teachers whenever noeded.

An important reason listed by the teachers for not using more mochanical alds was that of not being able to operate projectors. The filmstrip projector is very easily manipulated and could even be operated by a fifth or sixth grade child. While the motion picture projector requires more skill, yet any teacher can learn how to operate it in several lessons. Since these aids are most effective when used by a teacher in her own classroom situation each 
teacher should endeavor to operate the projectors herself. Over half of the teachers stated that they felt that audio-visual aids are too expensivo. This complaint is a just one as projectors and films are quite costly. If each school could purchase one fllm, these films could be placed at the Board of Education and be used by all the teachers throughout the school system. Thus a fairly good film library would be begun which no doubt would increase as teachers become more familiar and interested in these aids.

It is interesting to note that the great majority of the loading cities of the United States have wellorganised and functioning visual instruction departments. A small part of the list includes such familiar names as Blrmingham, Phoenlx, Berkeley, Long Beach, Ios Angeles, San Diego, San Francisco, Pueblo, Hartford, Bridgeport, Washington, D. C., Atlante, Bloomington, Gary, Indianapolis, Sloux City, Atchison, Winfleld, Cambridge, Dotro1t, Kalamazoo, Hibbing, Red Wing, Kansas City, St. Louls, Montclair, Nowark, Trenton, Albany, Itheca, New York C1ty, Schonectady, WInstonSalem, Chicago, Cleveland, Tolodo, Tulsa, Portland, Erio, Pittsburgh, Philadolphia, Reading, Scranton, Providence, San Antonio, RIchmond, Seattle, and many others in all parts of the United States.1

Many teachers stated that they did not know where to locate this type of material. The teachers should, of course, be informed of all the numerous places where audiovisual alds may elther be purchased, rented, or secured frov of charge.

Another group, amaller in number, claimed that they

1. Ellsworth C. Dent, The Audlo-V1sual Handbook (ChIcago: The Society for visual Educat Ion, I939), p. 5 . 
were not able to secure the material or the projector at the time they desired. This is a just complaint, especially in securing motion picture films. Since the Loulsville teachers must secure most of their films from the University of Kentucky or from film companies out of the state (which deliver flims to teachers all over the country) they often are unable to secure films at the time desired. As was stated before, if a film library could be advanced hore in Ioulsville, a system could be provided which would onable the teachers to secure films at times they wish. Making these audio-visual alds avallable to the teechers, and demonstrating to them how to operate projectors are just the initial steps. The most important phase of audio-visual ald education is that of instructing the teachers in the proper use of these alds. For if teachers are not properly trained, much of this material will be incorrectly used. Demonstration lessons should be presented displaying correct procedures to be employed in ut1lizing audio-visual aids in instruction. Bulletins relative to this topic should be sent to the teachers quite frequently. Classes in the effective use of audio-visual alds should be offered to the teachers in service. Fortunately, the University of Louisville has offered such a course during the last several sumers. This course has stimulated the 
Interest of a muber of Loulsville teachers in audiovisual alds and has ably assisted them in classroom use of same. Attending classes of this type should be required of every person entering the teaching profession. Study groups should also be formed to make a detalled study of these alds. Comittees of teachers should be encouraged to meet and plan discussions on these topics.

The following recommendations have elther been suggested by the teachers or grew out of this survey:

1. More audio-visual ald material should be provided for the white fourth, fifth, and sixth grade Louisville teachors.

2. Teachers should be made aware of the effectiveness of audio-visual alds by demonstration lessons, bulletins, suggest ed readings, lectures, and interviows.

3. Lessons in operating projectors should be given to all the teachers.

4. A bulletin liating the latest audio-visual ald materials avallable should be malled at least once a year to teachers. The price, source of supply, typo and use should be included in such bulletin. 5. Courses stressing types and advantages of audio-visual alds should be offered to teachers. 
6. All principals should, by correct administration and supervision, encourage and promote audio-visual aid programs in their respective schools.

It is hoped that the findings of this investigation will result in measures being taken to acquaint teachers with the many advantages of audio-visual a1ds in classroom instruction to the extent that they will be more widely used. While it is reelized that this survey is far from complete, and many questions remain unanswered, jet the investigator foels that a small contribution has been made in the fleld of education by examining a problem which heretofore has been neglected insofar as the Ioulsville public schools are concerned. 


\section{BIBLIOGRAPHY}




\section{BIBLIOGRAPHY}

Arnsplger, Varney C., Measuring the Effectiveness of Sound Plctures as Teaching Alds. New York: Teachers College, Columbia University, 1933.

Bathurst, Effie, Conservation Films in Elementary Schools. Washington, D. C.: U.S. Office of Education, 1941 .

Blumer, Herbert, Movieg and Conduct. New York: The Macmilian Company, 1933 .

Brown, H. Emett, and Bird, Joy, Motion Pictures and Lantern Slides for Elementary VisuaI Education. New York: Teachers College, Columbla University, 1931 .

Charters, W. W., Motion P1ctures and Youth, A Sumary. New York: The Kacmillan Company, 1933.

Clark, Ella, The Use of Visual Aids in Teaching. Winona,

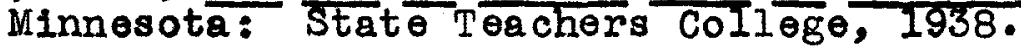

Dale, Edgar, and others, Motion Plctures in Education. New York: The H. W. WIIson Company, 1938.

Dent, Ellsworth C., The Audio-V1sual Handbook. Chicago: The Society for Visual Education, 1939 .

Dunlap, Orrin, Story of Radio. New York: Lincoln MacVeagh - The DIal Press, 1927 .

Dysinger, Wendell, and Ruckmick, Christian, The Emotional Responses of Children to the Motion Picture Situation. New York: The Macmilian Company, 1933.

Ellis, Don Carlos, and Thornborough, Laura, Motion Plctures in Education. New York: Thomas Y. Crowell Company, 1923.

Floherty, John, On the Air, the Story of Rad1o. New York: Doubleday, Doran and Company, 1938.

Forman, Henry, Our Movie Made Children. New York: The Macmillan Company, 1934. 
Gray, H. A., Instructionel Sound Films Correlated with Public school Curriculum Materials. New York:

Erp1 Classroom Films, Inc., 1940.

Hamilton, George E., The Stereograph and the Lantern Slide in Educat ion. Meadvilio, Pennsylvania: Keystono View Compeny, 1935.

Hays, W1Il, See and Hear. Motion Plcture Producers and Distributors of America, November, 1939.

Hoban, Charles, Hoban, Charles, Jr., and Z1sman, Samuel, Visualizing the Curriculum. New York: The Cordon Company, 193\%.

Knox, Rose, School Activities and Equipment. Boston: Houghton Miffiln Company, 1927.

Koon, Cline M., School Use of V1sual Alds. Washington, D. C.: U. S. Department of the Interior, Department of Education, 1938.

Latchy, Josephine, Education on the A1r. Columbus: Ohio State University, 1931.

McKown, Harry, and Roberts, Alvin, Audio-Visual Alds to Instmuction. New York and London: McGran-HIII Book Company, 1940 .

Peterson, Ruth, and Thurstone, I. I., Motion Plctures and the Social Attitudes of Children. Now york: The Hacmilian company, I933.

Ransaye, Terry, M1lilion and one Nights. New York: Simon and Schuster, 1926 .

Tyson, Levering, and Donovan, William J., Retrospect and Forecast in Radio Education. Chicago: The University Press, I936.

Weber, J. J., V1sual Alds in Education. Valparaiso, Indiana: Valparaiso University. 1930.

Wood, Ben D., and Freemen, Frank, Motion Pictures in the Classroom. Boston: Houghton Miffin Company, 1929. 
YEARBOOKS

"Alds to Teaching in the Elomentary School," Thirteonth Yearbook, Department of Elementary Principals.

NationaI Education Association, 1934 .

"Materials of Instruction," Eighth Yearbook, Depertment of Suporvisors and Directors or Instruction, National Education Association. New York: Bureau of Publications, Teachers College, Columbia University, 1935.

\section{PERIODICALS}

Bradley, Walter, Visual Aids to Education. Unpublished Master's thesis, The University of Michigan, 1937.

Brien, Manson Milner, "Notes on the Histor1cal Background of Visual Education," Education. 61: 322, Febmary, 1941 .

Harap, Henry, "Scope of an Effect1ve School Program for Utilizing Community Resources," Elementary School Princ1pal, Elghteonth Yearbook, July, 1939.

Harper, R. A., and Otto, Henry J., "An Evaluation of Graphlc Instruction Materla1s," Thirteenth Yearbook, National Elementary Principal, June, 1934.

Knowlton, Daniel, and Tilton, Warren, "Improving the Quality of Instruction in History with the Ald of the Photoplay," The Histor10al Outlook. 20:167-179, 229-239.

Krasker, Abraham, "A Critical Anelysis of the Use of Educational Motion Pictures by Two Methods," Educational Screen, September, 1941.

May, Mark, "Educational Possibilities of Motion Plctures," The Journal of Educational Sociology, November, 1937. 
Moad, Cyrus D., "Visual vs. Teaching Method - An Experiment," Educational Administration and Supervision. $13: 505-518$, November, 1927.

Meador, Mildred, "Are Pictures an Effective Aid in the Teaching of Geography ?" Educatlonal Method, November, 1931 .

Rulon, Philifp J., "The Sound Plctures in Solence Teaching," Harvard Studies in Education. Cambridge, Massachusotts: Harvard University Pross, 1933.

Thomas, Wendell, "The Stream of Perceptual Teaching," Ecucational Screen, November, 1939.

Wisconsin University Research Comittee, "Wisconsin Tests Value of Radio in the Classroom," School Iife. 16: 104-105, February, 1931.

Wood, Ben D., and Freeman, Frank, "Summary of Research," Thirteonth Yearbook, National Elementary Principal, June, 1934. 
APPENDIX 
SAMPLE OF LETTER AND QUESTIONNAIRE MAILED TO EVERY LOUISVILLE WHITE ELEMENTARY SCHOOL 
Louisville, Kentucky

November $29,1941$.

Doar H1ss :

Dx. Z. E. Scott has kindly consented to my making a study in our elementary schools to determino which types of audio-visual aid material are boing used, about how frequentij, the ways they are being us ed, and their value to teachers in instmuction.

Becease I an extremely interested in this subject, I am making this survey as part of my thosis.

I have made questionnaire as concise as possible so thet it can be answered in a very short t1me. Will you kindly submit the questionnaire to each of your fourth, fifth, and sixth grade teachers to bo answered by them? If possible, I would like to have the questionnaire returned to me by December 16.

Allow mo to express my sincerest appreciation to you and jour teachers for your cooperation. I w1II bo glad to send you the results of survey if you so desire.

Yours truly,

Olga Schmatz

George W. Morris School - 6A-B

Inclosure:

Quest ionnaire 
I. Did you use any of the following audo-visual ald materials during 1940-1941?

\begin{tabular}{|c|c|c|c|c|}
\hline Never & $\begin{array}{l}\text { How } \\
\text { Frequently } \\
\text { (approxi- } \\
\text { mately) }\end{array}$ & $\begin{array}{l}\text { Chook } \\
\text { Those } \\
\text { about Which } \\
\text { You Know } \\
\text { Nothing }\end{array}$ & $\begin{array}{l}\text { Cheak } \\
\text { Those in } \\
\text { Whioh You } \\
\text { Are Most } \\
\text { Interested }\end{array}$ & $\begin{array}{l}\text { Chook Those } \\
\text { about Whioh } \\
\text { You Desire } \\
\text { More In- } \\
\text { formation }\end{array}$ \\
\hline
\end{tabular}

Sohool Excursion
A. Trips to industrial plants -...
B. Trips to parks -
C. Trips to civic institutions (post office, 11brary, otc.) -..
D. Trips to observe phrsical features of the earth (river, hills, stars, clouds, etc.) -... Objects - Specimens - Models - - m-nGraphs -..-_-_Cherts and Diagrams Maps and Globes

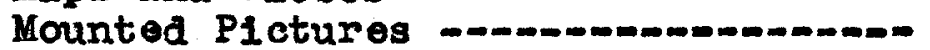

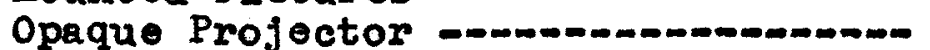
Stereoscopes Lantern SIIdes F1lmstrips Motion P1ctures -n. Microscope Slides Phonograph Records -

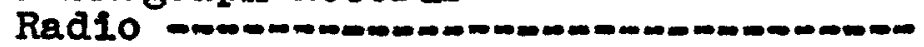


II. If there are any audio-visual a lds listed on reverse side that jou have never used, or have used very seldom, please check the reasons given below that apply to your case.

1. Unable to operate projector.

2. Do not know where to locate material (filmstrip, films, etc.)

3. Materials (films, slides, flimstrips, etc.) are too expensivo.

4. Unable to secure material at desired time.

5. Unable to secure projector at desired time.

6. Unable to secure sultable materlal for work or grade.

List any other reason not given above. 
III. Check the following ways in which audio-visual material has best answered your need in teaching.

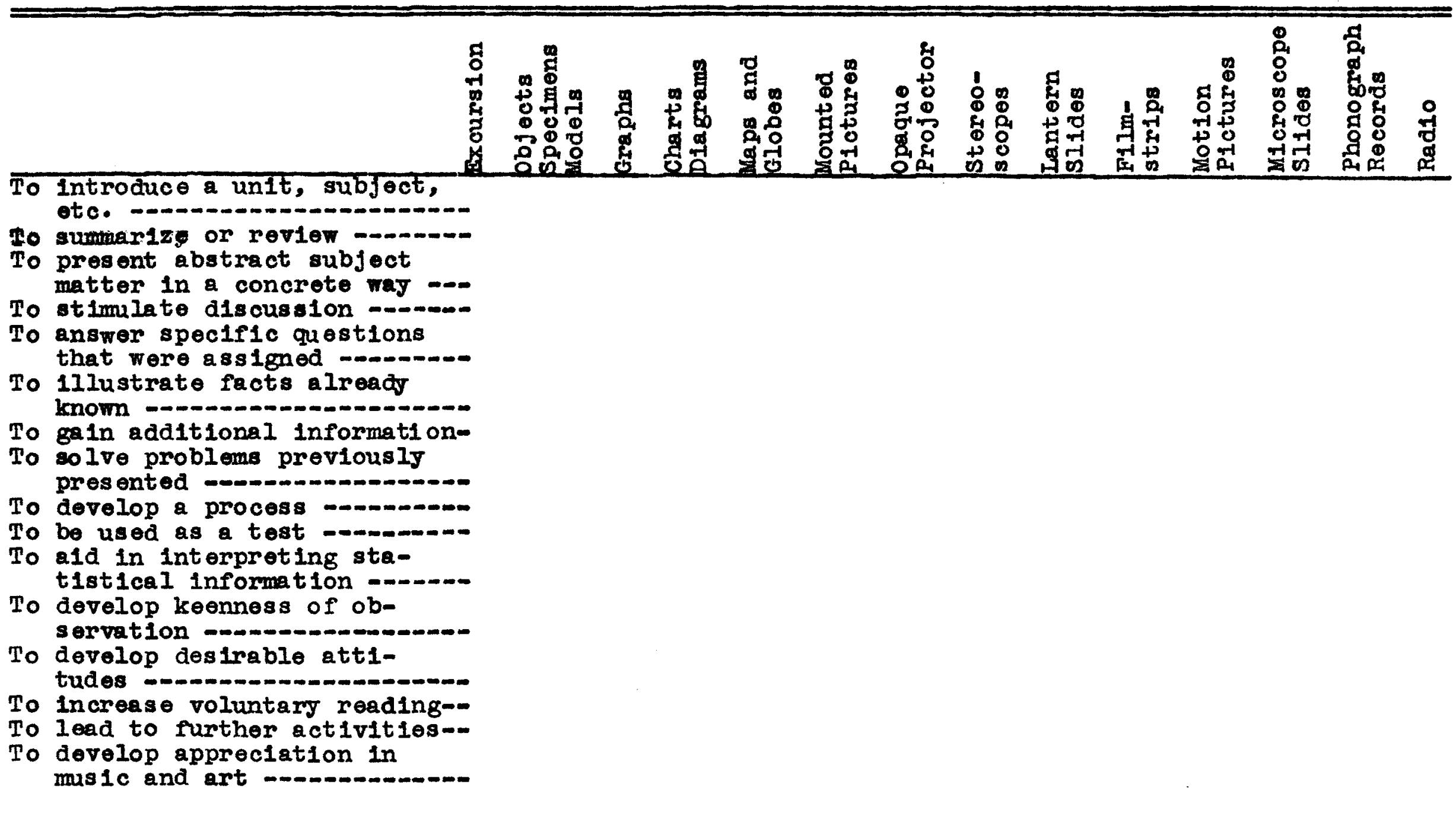




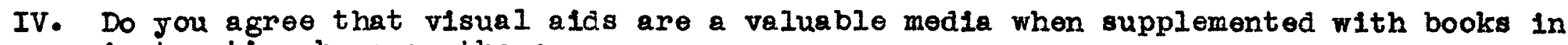
instruction because theJ:

Yes No

Arouse interest of chilaren.

Increase the learning of pupils.

Increase the retention of material.

Increase participation in classroom discussion.

Ald class in interproting aifficult facts.

Lessen problems of discipline.

Provide ind Ividual instruction for pup118.

Bring pupils into direct contact with reel experiences.

Provide a means of enriching experience of pup1ls.

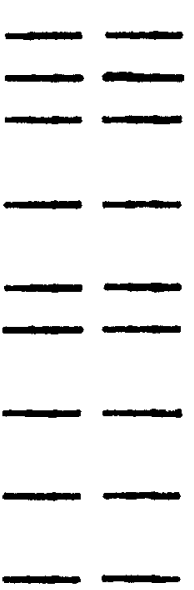

Yes No

Provide a real opportunity for choosing, purposing, planning, executing and eveluating on the part of pupils.

Stimulate narration and discussion.

Increase cooperation and discussion.

Effects on economy of time in

learning.

Aid in teaching backward chilaren.

Enrich and vary classroom activity.

V. What suggestions or recommendations could you make for establishing an audio-visual ald program? 
COMPLETE TABULATION OF RESUITS OBTAINED FROM FINDINGS OF THE QUESTIONNAIRE 
I. Did you use any of the following audio-visual aid materials during 1940-1941?

\begin{tabular}{|c|c|c|c|c|c|c|}
\hline & \multicolumn{6}{|c|}{ (Expressed in Percentages) } \\
\hline & Never & \multicolumn{2}{|c|}{$\begin{array}{l}\text { Hov } \\
\text { Frequent ly } \\
\text { (approxi- } \\
\text { metely) }\end{array}$} & $\begin{array}{l}\text { Chook } \\
\text { Those } \\
\text { about Which } \\
\text { You Know } \\
\text { Nothing }\end{array}$ & $\begin{array}{l}\text { Cheok } \\
\text { Those in } \\
\text { Which You } \\
\text { Are Most } \\
\text { Interested }\end{array}$ & $\begin{array}{l}\text { Check Those } \\
\text { about Which } \\
\text { You Desire } \\
\text { More In- } \\
\text { formetion }\end{array}$ \\
\hline 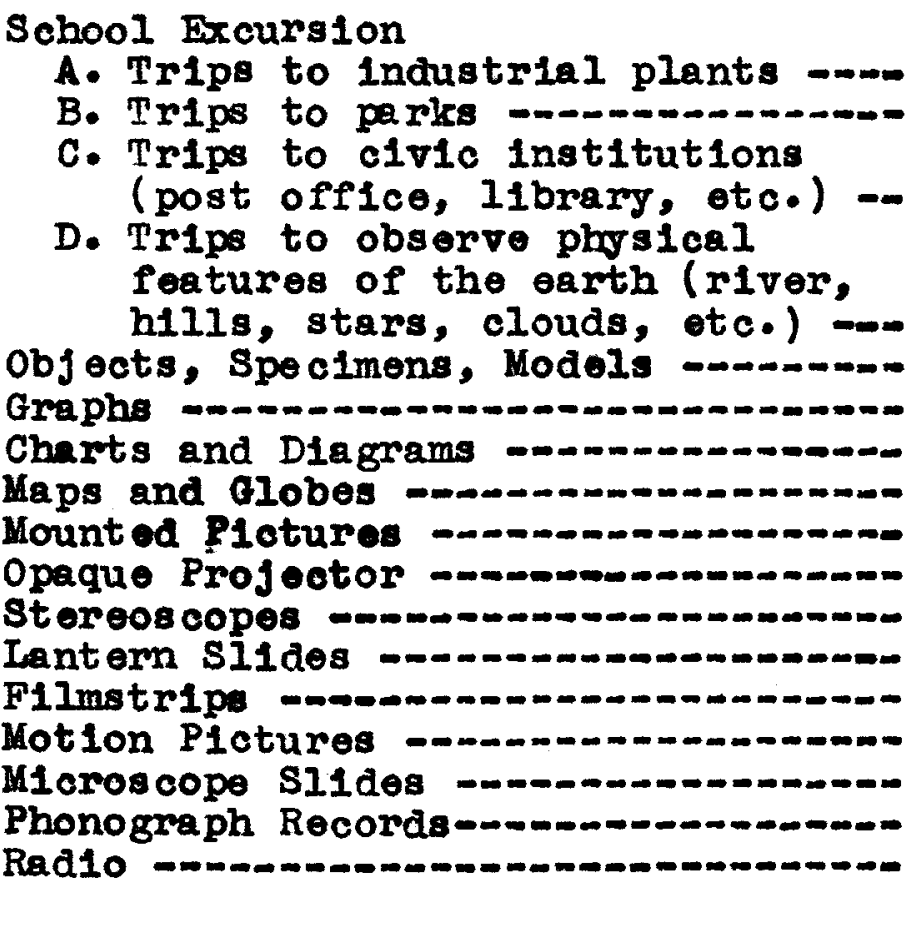 & $\begin{array}{r}86 \\
27 \\
28 \\
18 \\
4 \\
8 \\
100 \\
88 \\
86 \\
89 \\
52 \\
94 \\
60 \\
30 \\
\end{array}$ & $\begin{array}{r}14 \\
34 \\
42 \\
34 \\
15 \\
28 \\
-0 \\
10 \\
11 \\
11 \\
43 \\
6 \\
34 \\
59\end{array}$ & $\begin{array}{r}-1 \\
39 \\
30 \\
48 \\
81 \\
64 \\
-10 \\
2 \\
3 \\
-5 \\
-6 \\
11\end{array}$ & $\begin{array}{r}1 \\
-\infty \\
-\infty \\
-\infty \\
-\infty \\
43 \\
13 \\
8 \\
17 \\
5 \\
7 \\
2 \\
1\end{array}$ & $\begin{array}{r}10 \\
30 \\
19 \\
21 \\
38 \\
33 \\
7 \\
10 \\
14 \\
16 \\
48 \\
6 \\
26 \\
41\end{array}$ & $\begin{array}{r}5 \\
3 \\
-1 \\
2 \\
1 \\
2 \\
26 \\
10 \\
14 \\
22 \\
22 \\
6 \\
4 \\
6\end{array}$ \\
\hline
\end{tabular}


II. If there are any audio-visual alds listed on reverse side that you have never used, or have used very seldom, please check the reasons given below that apply to your case.

1. Unable to operate profector. $58 \%$

2. Do not know where to locate material (filmstrip, films, etc.) $40 \%$

3. Materials (films, slides, filmstrips, etc.) are too expensive. 52\%

4. Unablo to secure material at desired time. $28 \%$

5. Unable to secure projector at desired time. $20 \%$

6. Unable to secure suitable material for work or grade. $22 \%$

List any other reason not given above.

4\% ola imed building not equipped for projection. 
III. Check the following ways in which audio-visual material has best answered your need in teaching.

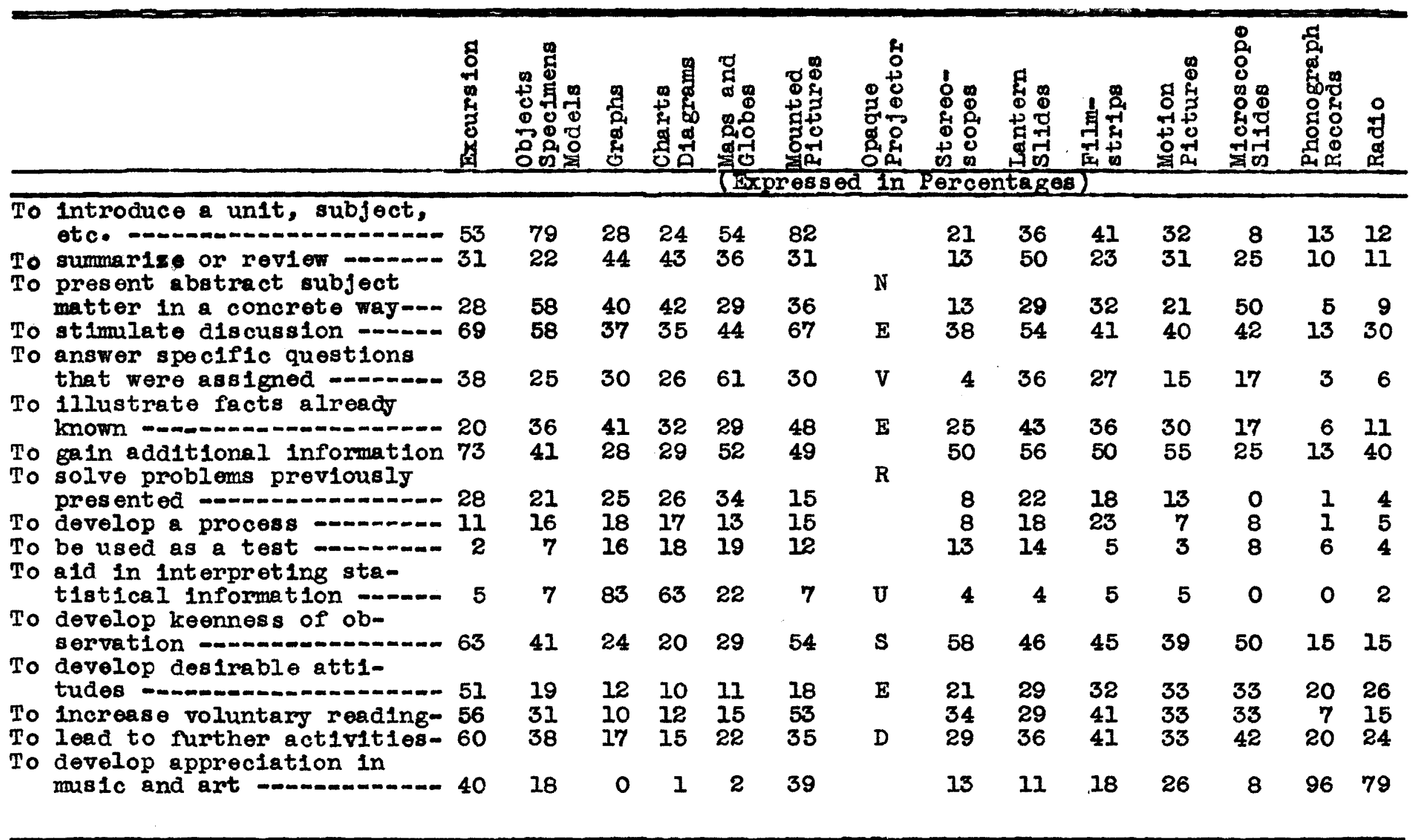


IV. Do you agree that visual alds are a valuable medie when supplemented with books in instruction because they:

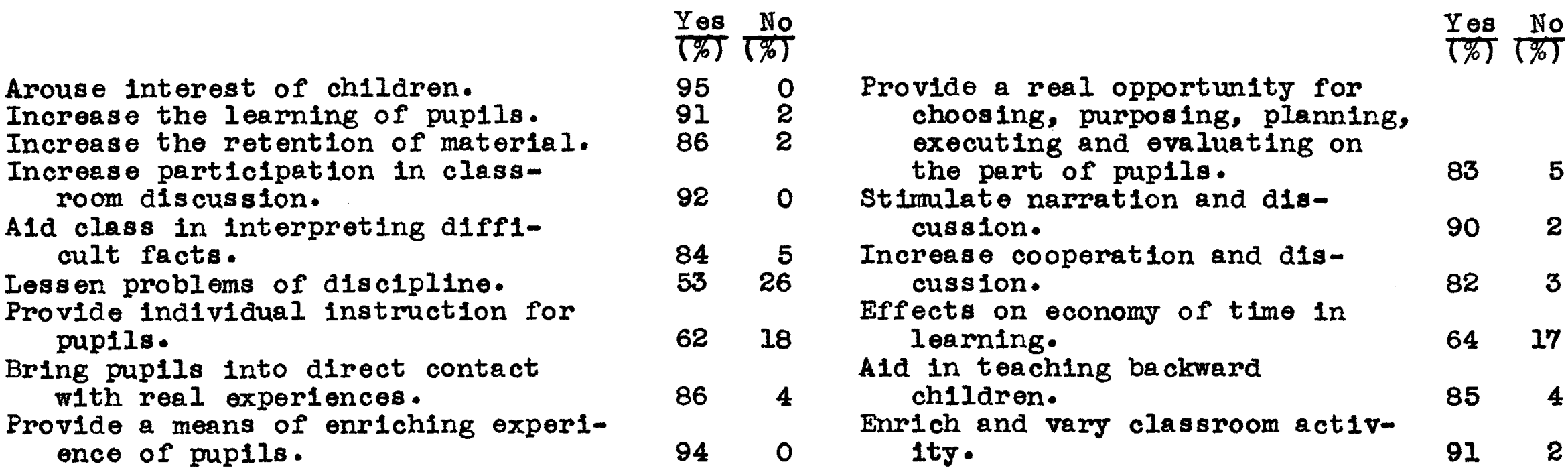

V. What suggestions or recommendations could you make for establishing an audio-visual aid program? *

* These have been Incorporated in Chapters V and VI. 
VISUAL INSTRUCTION EQUIPMENT OF LOUISVILIE BOARD OF EDUCATION 
VISUAL INSTRUCTION EQUIFMENT OF LOUISVILLE

BOARD OF EDUCATION - 1942

Quantity

3

1

2

48

22

600
Equipment

$16 \mathrm{~mm}$. Sound on Film Projectors

Glass SIlde and Opaque Projector

Strip Film Projectors

Stereoscopes

Filmstrips - Geography of the United States A. Now England

B. Appalachian Mountains and Valleys

C. Atlantic Coastal Plain and Pledmont Plateau

D. Gulf Coastal Plain

E. Inland Seas and Waterways

F. Mldwest Plains and Plateaus

G. M1d-South Plains and Platerus

H. Rocky Mountains and Plateaus

I. Pacific Slope

J. Alaska, Panama Canal Zone, Hawalian Islands, Outlying Possessions

SIIdes and Stereographs - "Keystone Set" of Lantern SIlices and Stereographs

I. Geography

A. Geographical Classification and Title List

B. People of all Lands

C. Production and Manufacturing

D. Transportation

E. Markets and Marketing

F. Natural Forms and Forces

G. Zones and Their Effects on Iife, Elevation of Land, and Its Effect on Life

H. Geography by Nations

I. Earth Neighbors

II. History and Civics

A. Forelgn Beginnings of American History 
Quantity 
Quantity

Equ ipment

B. House Design and Decoration, Costume Design

C. Photography

IX. For the Little Folks

A. Children of the World, Including Home Iife

B. Plants and Animals

C. Reading

D. Some Things We Eat: Some Things We Wear

E. Home Geography

F. Travelogue and Lecture Suggestions 